\title{
Analysis of Vortex Pool-and-Chute Fishway
}

\author{
Mathew Nyberg, Brian Draeger, Brian Weekly, Eileen Cashman*, Michael Love \\ Department of Environmental Resources Engineering, Humboldt State University, Arcata, CA \\ Students:mjn190@bumboldt.edu,bd539@bumboldt.edu,brw167@bumboldt.edu \\ Mentors: eileen.cashman@humboldt.edu*,mlove@h2odesigns.com
}

\begin{abstract}
Fishways are constructed in riverine habitats where structures such as culverts, dams, and flood channels have negatively impacted flow conditions suitable for the movement of native and migratory fish species. These auxiliary channels are engineered to resist gravitational force with frictional force, resulting in sustained depth and reduced velocity over a range of design flow rates. The Chézy hydraulic resistance coefficient accounts for such forces and provides a metric useful for determining the effectiveness of a fishway to alter flow conditions prohibitive to the passage of fish. The objective of this analysis was to use a scale model of an innovative vortex pool-and-chute fishway, that operates with both plunging and streaming flow simultaneously, designed by Michael Love and Associates, to determine the Chézy resistance coefficients over a range of flow rates under controlled hydraulic conditions. Using dimensional analysis to ensure proper scaling allowed laboratory measurements of the model to be translated into a real-world prototype design. The conceptual prototype fishway is a 144 -foot-long by 30 -foot-wide channel with an $8 \%$ slope. A 1:15 scale model was constructed to evaluate the design at prototype equivalent flow rates between 58 and 283 cubic feet per second (cfs). Chézy coefficients were estimated by two different calculation methods; the streaming flow method and the streaming and plunging flow method. Coefficients ranging between 22.3 and $39.2 \mathrm{ft}^{1 / 2} / \mathrm{s}$ were determined by the streaming flow calculation method, whereas the streaming and plunging flow calculation method yielded estimates from 18.9 to $25.0 \mathrm{ft} \mathrm{ft}^{1 / 2} / \mathrm{s}$ at corresponding flow rates. For flows that were exclusively plunging, values of 32.2 to $41.9 \mathrm{ft}^{1 / 2} / \mathrm{s}$ were found. In general, Chézy coefficient estimates were observed to decrease with increasing discharge and values were found to be comparable to those calculated for fishways implemented at similar slopes. The preliminary model fishway results indicated that implementation of a prototype fishway could effectively alter flows for adequate fish passage under the given conditions.
\end{abstract}

\section{KEYWORDS}

Hydraulics; Fish Passage; Fishway; Chézy Coefficient; Geometric Scaling; Froude Scaling; Streaming Flow; Plunging Flow; Dimensional Analysis; Similitude

\section{INTRODUCTION}

The development of man-made structures within natural waterways has resulted in the decline of native fish species due to the ensuing unfavorable flow conditions. Consequently, engineers have designed secondary structures to create environments suitable for the movement and migration of fish within affected stream areas. Several types of fish passage structures have been developed, including fish elevators and various fish ladder designs. The objective of this project was to provide an analysis of a vortex pool-and-chute (VPC) fish ladder designed by Michael Love and Associates (MLA) proposed for Alameda Creek in Alameda County, California. Due to urbanization in the Alameda Creek watershed, channelization and man-made barriers designed for flood control have made the creek prohibitive for native steelhead trout migration. The fishway analyzed is a scaled model of the prototype designed by MLA. The prototype design is a 144-foot-long by 30-foot-wide VPC fishway, positioned on an $8 \%$ slope. Eleven chutes with vortex weir shoulders, chamfered on the downstream edge to minimize adhesion, are evenly distributed along the fishway with the goal of adequately accommodating fish passage over a range of flow rates between 20 cfs and $200 \mathrm{cfs}$. To ensure similitude, geometric and Froude scaling were conducted to convert geometric and flow parameters between the model and prototype fishways. The scale model of the prototype was built in The Humboldt State University (HSU) Environmental Resources Engineering Construction Laboratory. The fishway was constructed using half-inch thick Plexiglas ${ }^{\circledR}$ due to the similar roughness characteristics of the concrete prototype.

The HSU sediment transport flume was utilized to evaluate the scale model's performance over a range of discharges. The flume is equipped with two pumps capable of supplying up to 700 gallons per minute (gpm) to a two-foot-deep, two-and-a-half-footwide by forty-foot-long channel. Fluid enters the channel and supply line gate-valves enable regulated flow. A mounted point depth gauge with latitudinal and longitudinal adjustments provides for three-dimensional measurement within the channel. A hinged mount at the flume head and pneumatic jack at the tail of the channel allow for slope modification. Together these flume characteristics enable collection of data under controlled hydraulic conditions. 
While it is essential that the fishway reduces flow velocity and maintains adequate depth for fish passage, it is also important that the flow rate is sufficient to attract fish to the fishway entrance. An analysis of the collected data was carried out to estimate the Chézy coefficient of the fishway at various flow rates. The Chézy coefficient is a measure of resistance to flow and is a function of gravity and the roughness of the material over which uniform flow occurs in an open channel. With a known Chézy coefficient and fishway geometry, flow rates and associated velocities may be estimated for the fishway. Results from the scaled model analysis will assist MLA in determining whether the fishway will allow sufficient flow to attract fish while providing adequate resistance to create a favorable environment for the successful passage of native migratory fish species.

\section{Fishway Basics}

The standard pool-and-weir is the basic fishway design, where stream flow is altered by channel spanning weirs that effectively divide the stream section into pools. Depending on the magnitude of discharge, one of two flow regimes exists: plunging or streaming. These regimes are characterized by the manner in which the water circulates within the pools. At lower rates, flow plunges over the weir crests into the downstream pool and follows a path downward to the channel bottom, along the bed in the downstream direction, and then rises at the upstream side of the subsequent weir face. A portion of the flow rises and spills over the weir crest into the next pool while some of the flow travels back upstream, causing a circulation pattern that is distinct from the streaming flow regime. ${ }^{1}$ The described circulation pattern for the plunging flow regime is illustrated by the flow lines shown in Figure 1. Given that pool sizes are sufficient to dissipate turbulence caused by plunging flows, conditions in this regime are favorable for fish passage. The inclusion of orifices at the bottom of the weirs further supports this plunging circulation pattern and can extend the range of flows over which the plunging regime persists. ${ }^{1}$

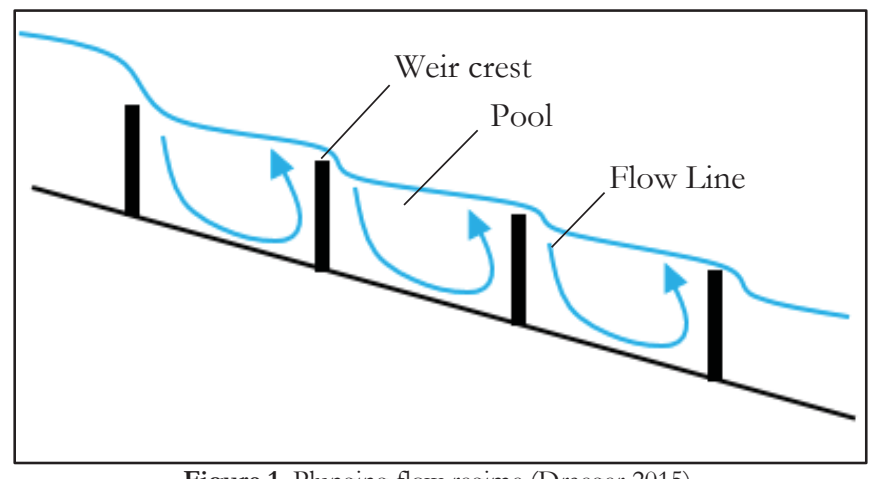

Figure 1. Plunging flow regime (Draeger 2015).

Higher flow rates result in streaming flow conditions, characterized by higher velocity flows that skim over the pool water surfaces and above the weir crests. A circulation pattern in the opposite direction of that described for plunging flow results due to the effects of shear stresses propagating through the water. The streaming flow regime circulation pattern is shown by the flow lines in Figure 2 and is not conducive to fish passage.

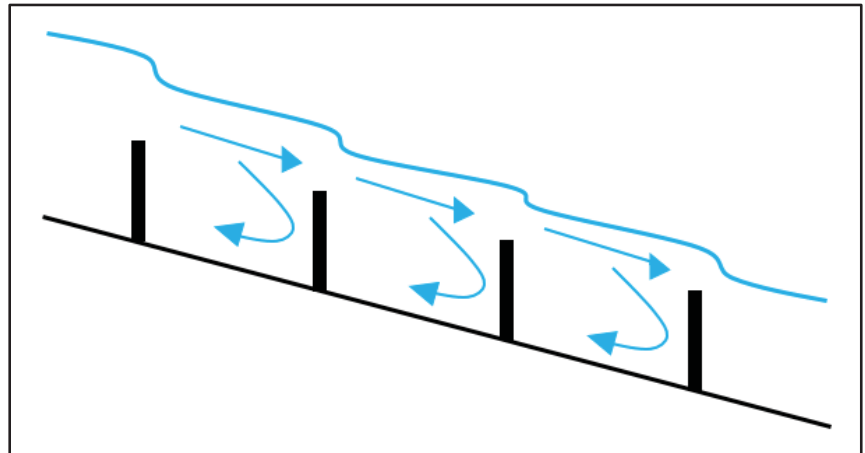

Figure 2. Streaming flow regime (Draeger 2015).

The relative elevations of the weir crests and the downstream pool water surface distinguish the difference between plunging flow and streaming flow. In plunging flow conditions, the downstream pool water surface is below the upstream weir crest. ${ }^{2} \mathrm{When}$ the downstream pool elevation surpasses the weir height, the influence of the weir diminishes, ultimately leading to the change in circulation pattern where streaming flow begins. Higher flow rates result in streaming flow conditions in which the downstream pool water surface elevation is higher than the upstream weir crest. ${ }^{2}$ Once streaming flow begins in the pool-and weir design it occurs across the entire width of the fishway, resulting in velocities and hydraulics not suitable for fish passage. 


\section{Pool-and-Chute Fishways}

Pool and chute style fishways are commonly used for passage of steelhead trout and rely on the leaping ability of the fish to ascend the fishway. These types of fishways are typically designed for a specific range of flows and to meet the following objectives: 1) to create a fishway entry that is suitable for fish attraction, 2) to establish small water surface variances between neighboring fishway pools, 3) to develop sufficient pool volumes based on proper geometries to disperse energy and permit fish resting, 4) to establish plunging flows near the fishway walls, 5) to satisfy minimum water depth constraints for fish jumping, and 6) to satisfy maximum water velocity constraints in the fishway to ensure passage. ${ }^{3}$ A pool-and-chute fishway, as shown in Figure 3 has a notched "chute" in the center and shoulder weirs. They operate with streaming flow down the center of the fishway, in the chute, and plunging flows along the edges of the wetted shoulder weirs. A fish passage corridor is provided along the edges of the fishway, where flows are plunging, while the majority of the flow in the fishway is streaming down the center. This allows the fishway to have a wider range of operating flows, and the higher velocities of the streaming flows discharging from the fishway assist fish in locating the fishway entrance. Orifices may be included near the bottom of the structure and can positively affect the hydraulics of each successive downstream pool. Properly sized orifices, with a combined capacity that does not exceed the low flow of a stream, can provide fish passage throughout the dry season. ${ }^{3}$ These orifices also provide a route for passage of lamprey and other non-leaping fish species, and affect circulation patterns within the pool that improve sediment transport capacity through the structure. ${ }^{4}$

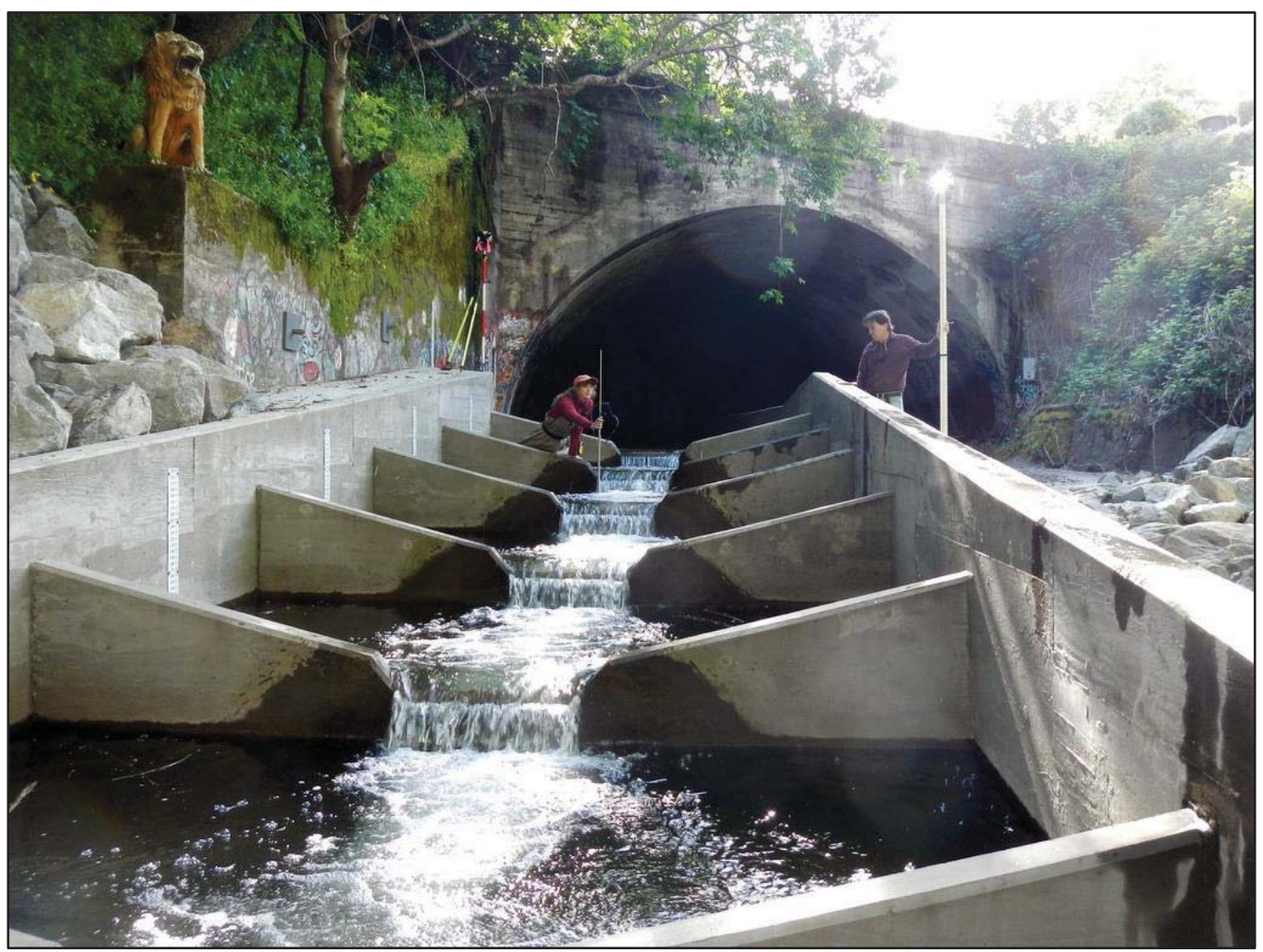

Figure 3. Downstream view of a partial-spanning pool-and-chute fishway in San Anselmo Creek, Marin County, California. ${ }^{5}$

Vortex Pool-and-Chute Fishway Design

The VPC fishway designed by Michael Love is a relatively distinct design. The vortex weirs are not only V-shaped downward to the channel center, but are also V-shaped longitudinally, with the apexes located in the upstream direction. The current design being analyzed in this document incorporates the pool-and-chute design and includes orifices within the vortex weirs (Figure 4 and Figure 5). 


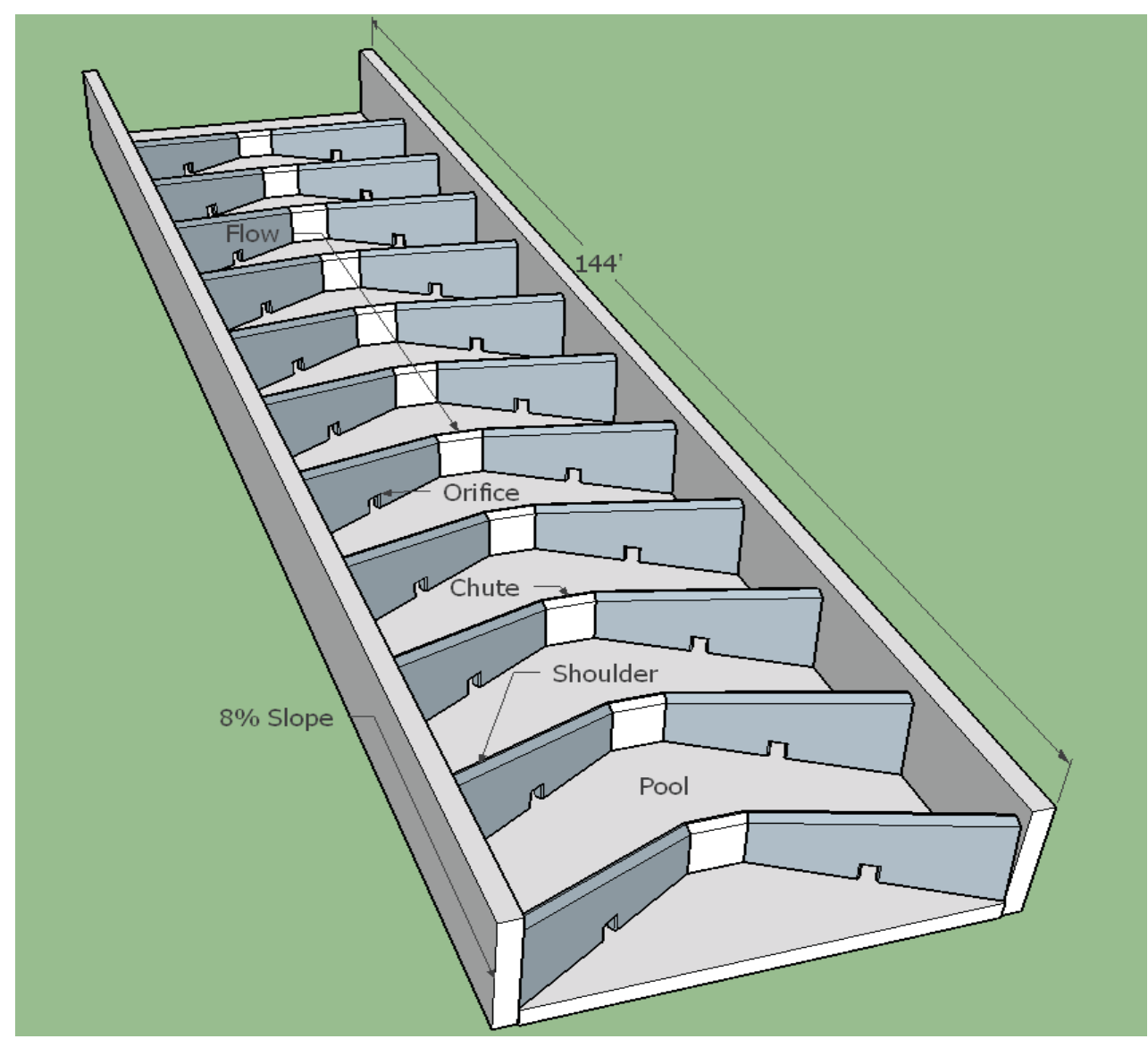

Figure 4. Downstream view of the Vortex Weir Pool-and-Chute Fishway Design prototype (Love and Associates 2015).

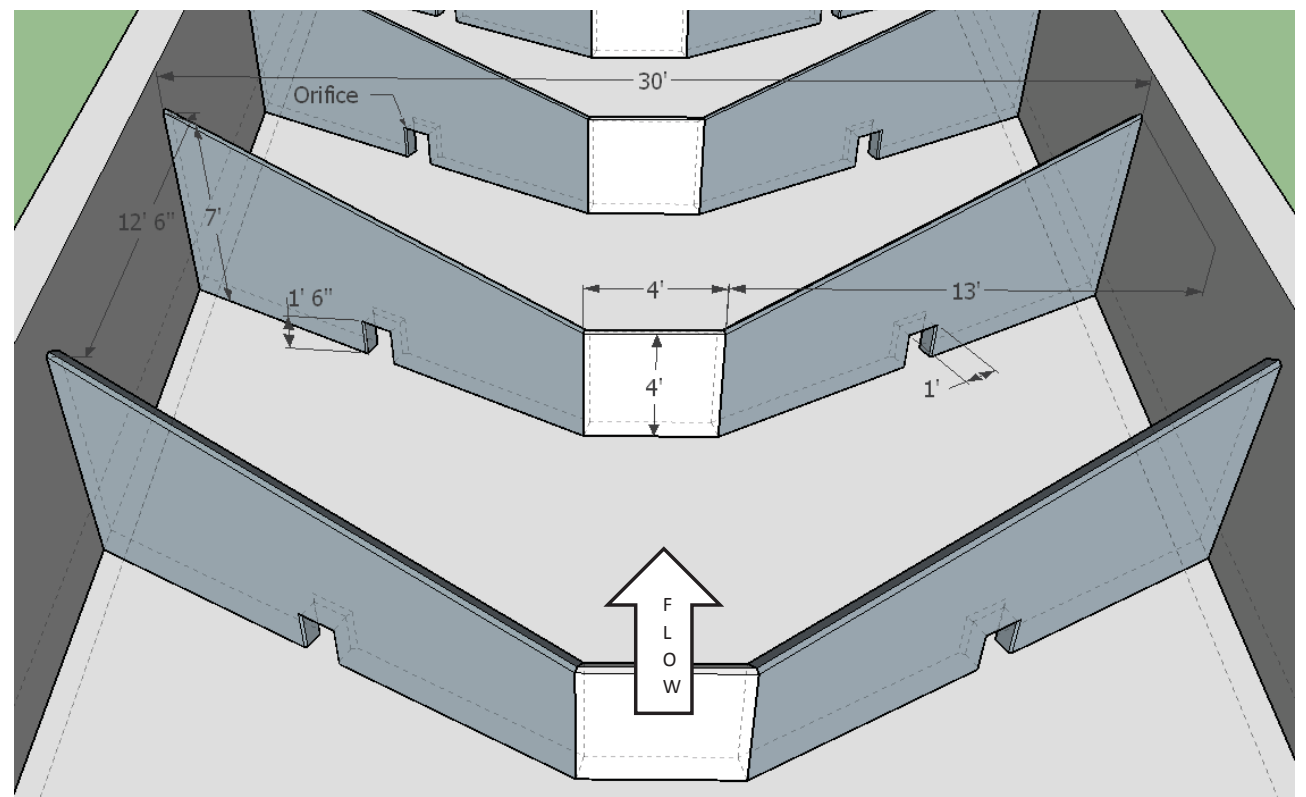

Figure 5. Section dimensions of the Vortex Weir Pool-and-Chute Fishway Design prototype (Love and Associates 2015).

In general, the vortex weir configuration serves to provide better flow conditions for fish passage relative to straight weirs by directing flow towards the channel center, thus reducing turbulence along the edges of the corridor. The VPC fish passage design allows for conveyance under both streaming and plunging flow regimes which may occur simultaneously across the fishway. ${ }^{6}$ At lower discharges, the design permits fish passage under plunging flow conditions. ${ }^{7}$ Flows are concentrated within the center of the 
fishway to promote scour, which effectively maintains pool volumes and dissipates flow energies while maintaining a slower and less turbulent corridor, along the margins of the fishway, suitable for fish passage. At higher discharges, steaming flow is focused to the center of the fishway while the $\mathrm{V}$-shaped weirs reduce velocity by extending crest lengths and maintaining plunging zones along the flow boundaries. ${ }^{7}$ Fish are able to pass through the lower velocity plunging flows that occur near the sidewalls of the structure. ${ }^{1}$ These zones provide jump heights of one foot or less, as required by the National Marine Fisheries Service design criteria for the target species (steelhead trout). ${ }^{8}$

\section{Scaling}

The geometric similarity between a model and a prototype must be preserved to determine potential prototype performance. All dimensions of the model and prototype must have an equivalent linear scale ratio in the x-, y-, and z-dimensions to be considered geometrically similar. Adhering to geometric similarity ensures that all angles within the prototype design are maintained in the scale model. ${ }^{9}$ The model fishway used in this analysis was constructed with a scaling ratio of 1:15 from the prototype design schematics to ensure geometric similarity. In addition to proper geometric scaling, Froude scaling was carried out so that the model and prototype had the same time scale ratio. This is referred to as kinematic similarity. ${ }^{9}$ Froude scaling provides a means to resolve the nonlinear relationship between model and prototype flow rates and velocities.

\section{Uniform Flow and the Chézy Equation}

When water depth remains constant throughout a specified reach of an open channel, the flow is classified as uniform flow. Uniform flow commonly occurs in prismatic channels of constant slope and cross-sectional area. ${ }^{10}$ In addition to a constant flow depth of $\mathrm{y}_{\mathrm{n}}$, velocity within the channel reach also remains constant. Considering equivalent velocities along the channel reach, the velocity heads drop out of the energy equation. ${ }^{9}$

$$
h_{f}=z_{1}-z_{2}=S_{0} L .
$$

Therefore, the headloss $\left(b_{f}\right)$ over the channel reach is equal to the loss in channel elevation $\left(z_{1}-z_{2}\right)$ or slope $\left(S_{0}\right)$ times the length (L). Headloss is also given by the Darcy-Weisbach equation:?

$$
h_{f}=f \frac{L}{4 R_{h}} \frac{V_{0}^{2}}{2 g},
$$

Equation 2.

where:

$$
\begin{aligned}
f= & \text { friction factor } \\
R_{h}= & \text { hydraulic radius }(\mathrm{ft}) \\
g & =\text { gravitational acceleration }\left(\mathrm{ft}^{2} / \mathrm{s}\right) .
\end{aligned}
$$

By setting Equation 1 and Equation 2 equal, the following relationship results for uniform flow channel velocity. ${ }^{9}$

$$
V_{0}=\left(\frac{8 g}{f}\right)^{1 / 2} R_{h}^{1 / 2} S_{0}^{1 / 2}
$$

Equation 3.

Under uniform flow conditions with a constant water depth, the value $\left(\frac{8 g}{f}\right)^{1 / 2}$ is constant for a given channel shape and roughness ${ }^{9}$ and is often denoted as $C$, the Chézy resistance coefficient. ${ }^{10}$

The following equations are known as the Chézy formulas; ${ }^{9}$

$$
\begin{aligned}
& V_{0}=C\left(R_{h} S_{0}\right)^{1 / 2}, \\
& Q=C A\left(R_{h} S_{0}\right)^{1 / 2},
\end{aligned}
$$

Equation 4.

Equation 5.

where $\mathrm{A}=$ area of flow in the cross section $\left(\mathrm{ft}^{2}\right)$. Given the channel geometry and flow rate, the Chézy coefficient can be solved as ${ }^{9}$

$$
C=\frac{Q}{A\left(R_{h} S_{0}\right)^{1 / 2}} .
$$




\section{METHODOLOGY}

To determine the Chézy coefficient for the VPC fishway, a number of flow calculations were required. The water depth above the weir at which flow transitions from plunging to streaming was estimated so that a distribution of the two regimes could be estimated for a given flow rate. The assumption was made that shallower depths along the weir crest were plunging. Based on empirical data from previous work, the following is a step-by-step set of instructions used to calculate the Chézy coefficient at a given flow rate. ${ }^{11}$ With an established Chézy coefficient, the mean velocity at various flow rates was predicted for the prototype fishway.

\section{Plunging-Streaming Transition}

To estimate the depth over the weir where flow initially transitions from the plunging regime to the streaming regime $\left(H_{P T}\right)$, the transition flow rate must be calculated. This is done by first using a dimensionless relationship to approximate the flow over the horizontal section of the fishway weir where transition begins. A plot developed by Ead et al. and published in 2004 was used to determine the dimensionless flow rate based on the ratio of the on-center weir spacing and the weir crest height $(L / p)($ Figure 6). 12

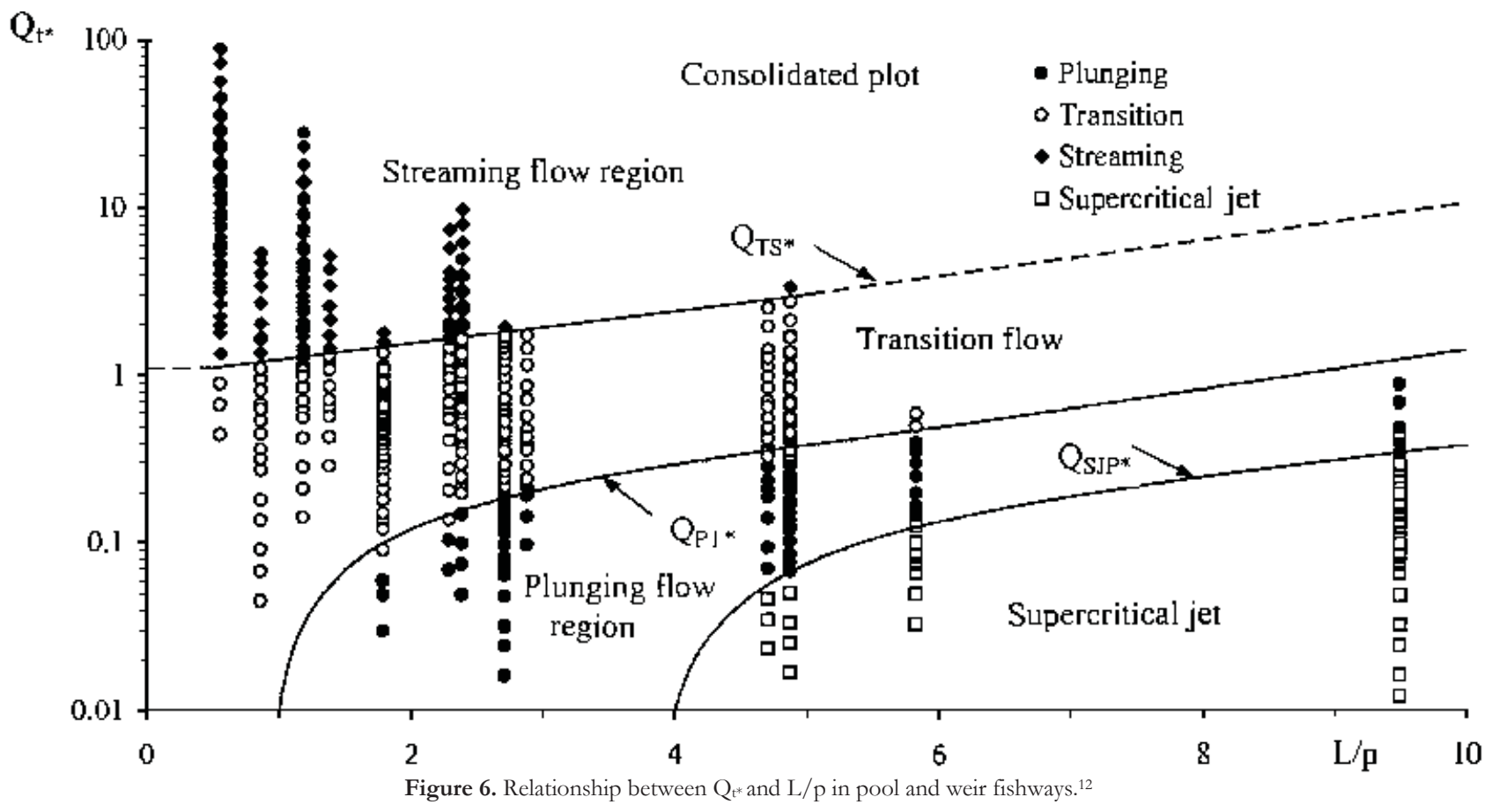

The values of $L$ and $p$ for the scale model fishway are $0.833 \mathrm{ft}$ and $0.267 \mathrm{ft}$, respectively. From the plot, the dimensionless plunging transition flow $\left(Q_{t^{*}}\right)$ for the fishway being analyzed was determined to be 0.22 and remains constant regardless of flow rate. The transition flow over the horizontal weir $\left(Q_{P T}\right)$ was then calculated to be ${ }^{12}$

where:

$$
Q_{P T}=Q_{t *} \sqrt{g} b_{0} S_{0} L^{3 / 2},
$$

Equation 7.

$$
\begin{aligned}
Q_{P T} & =\text { transition flow over horizontal weir crest }(\mathrm{cfs}) \\
Q_{t *} & =\text { dimensionless transition flow rate } \\
b_{0} & =\text { horizontal weir width }(\mathrm{ft}) \\
S_{0} & =\text { fishway slope }(\mathrm{ft} / \mathrm{ft}) \\
L & =\text { the on-center spacing of the weirs }(\mathrm{ft}) \\
g & =\text { gravitational acceleration }\left(\mathrm{ft}^{2} / \mathrm{s}\right) .
\end{aligned}
$$

The horizontal weir width $\left(b_{0}\right)$ for the model fishway is $0.267 \mathrm{ft}$. The transition flow rate $\left(Q_{P T}\right)$ for the model fishway was approximated to be $0.0203 \mathrm{cfs}$, and remains constant throughout this analysis. The depth of transition flow $\left(H_{P T}\right)$ was then calculated over the chute, at the flow rate found with Equation 7, utilizing a horizontal weir equation (Equation 8$).{ }^{13}$ The bracketed portion of Equation 8 is a correction factor to account for submergence. ${ }^{14}$ 
The corrected weir equation was rearranged and $H_{P T}$ was solved for using a numerical solver:

where:

$$
Q_{P T}=\frac{2}{3} C_{d} \sqrt{2 g} b_{0} H_{P T}^{3 / 2}\left[1-\frac{\left(H_{P T}-h\right)^{n}}{H_{P T}}\right]^{0.385},
$$

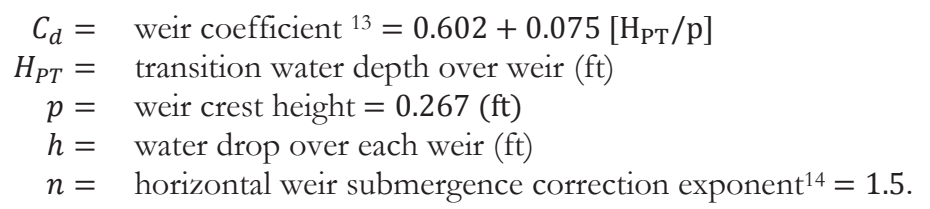

The fishway was designed such that the drop over each weir $(h)$ remains constant at $0.067 \mathrm{ft}(1 / 15 \mathrm{ft})$. Since the transitional water depth $\left(H_{P T}\right)$ is a function of only constants, this depth remains constant within the fishway regardless of the overall flow rate. The value of $H_{P T}$ was determined to be 0.984 inch $(0.082 \mathrm{ft})$ for the model fishway.

\section{Orifice Flow}

The fishway being analyzed includes orifices located at the bottom center of each shoulder weir; therefore, flow through these ports must be determined. This flow can be calculated using the standard submerged orifice equation: ${ }^{15}$

where:

$$
Q_{\text {orifice }}=C_{d} A \sqrt{2 g h}
$$

Equation 9.

$$
\begin{aligned}
Q_{\text {orifice }} & =\text { the flow rate through each orifice }(\mathrm{cfs}) \\
C_{d} & =\text { a coefficient used for the weir orifice } \\
A & =\text { the cross-sectional area of the weir orifice }\left(\mathrm{ft}^{2}\right) \\
h & =\text { water drops over each weir }=0.067 \mathrm{ft} .
\end{aligned}
$$

The common coefficient $\left(C_{d}\right)$ value used for chamfered orifices such as those found in the model fishway is $0.61 .{ }^{11}$ The crosssectional area of each orifice in the model fishway was determined to be $5.56 \mathrm{E}-3 \mathrm{ft}^{2}$. The water surface drop across the weir was constant at $1 / 15 \mathrm{ft}$, so the flow rate through each orifice $\left(Q_{\text {orifice }}\right)$ was approximated to be $0.007 \mathrm{cfs}$ and assumed constant regardless of the overall fishway flow rate.

\section{Plunging Flow}

The flow over the outer ends of the shoulder weirs, where depth is less than $H_{P T}$, is in the plunging regime. Utilizing the same submergence correction as used in Equation 8, a separate calculation was made using a standard sharp-crested triangular weir equation to approximate the plunging flow $\left(Q_{P L}\right):^{16}$

$$
Q_{P L}=\frac{8}{15} C_{d t} \sqrt{2 g} \tan \left(\frac{\theta}{2}\right) H_{v-w e i r}^{2.5}\left[1-\left(\frac{H_{P T}-h}{H_{P T}}\right)^{n}\right]^{0.385},
$$

where:

$$
\begin{aligned}
Q_{P L} & =\text { plunging flow rate }(\mathrm{cfs}) \\
C_{d t} & =\text { discharge coefficient for a triangular weir }{ }^{17} \\
& =0.6072-0.000874(\theta)+6.1 \times 10^{-6}(\theta)^{2} \\
\theta & =\text { angle of the opening in the triangular weir (degrees) } \\
H_{v-\text { weir }} & =\text { upstream depth above the triangular weir crest }(\mathrm{ft}) \\
H_{P T} & =\text { transition water depth over weir }(\mathrm{ft}) \\
n & =\text { triangular weir submergence correction exponent }=2.5 .
\end{aligned}
$$

\section{Streaming Flow}

The overall flow rate within the fishway $\left(Q_{\text {Fishway }}\right)$ was determined with the recorded stage in the flume head tank and the calibration curve provided for the HSU ERE sediment transport flume. The streaming flow rate $\left(Q_{S T}\right)$ was considered to be the portion of the overall flow rate that is not travelling through the orifices nor within the plunging flows near the fishway walls. 
The streaming flow rate was calculated as ${ }^{11}$

$$
Q_{S T}=Q_{\text {Fishway }}-Q_{P L}-2 Q_{\text {orifice }} .
$$

Equation 11.

Estimating the Chézy Coefficient $(C)$

The Chézy resistance coefficient was determined using two different methods over a range of flow rates. The first method used only the streaming portion of the overall flow to estimate the Chézy resistance coefficient. This method will be referred to as the streaming flow calculation method. The streaming flow rate $\left(Q_{S T}\right)$ calculated by Equation 11 was used in conjunction with the projected streaming flow hydraulic geometry over the chute and weir crest to calculate $C_{S T}:{ }^{11}$

where:

$$
C_{S T}=\frac{Q_{S T}}{A_{S T}} \sqrt{\frac{P_{S T}}{A_{S T} S_{0}}}
$$

Equation 12.

$$
\begin{aligned}
& C_{S T}=\text { Chézy coefficient calculated using } \mathrm{Q}_{\mathrm{ST}}\left(\mathrm{ft}^{1 / 2} / \mathrm{s}\right) \\
& A_{S T}=\text { wetted area over the weir within the streaming flow region }\left(\mathrm{ft}^{2}\right) \\
& P_{S T}=\text { wetted perimeter over the weir within the streaming flow region }(\mathrm{ft}) .
\end{aligned}
$$

The second method used the sum of the streaming and plunging portions of the overall flow to estimate the Chézy resistance coefficient. This method will be referred to as the streaming and plunging flow calculation method. The sum of the streaming and plunging flow rates $\left(Q_{S / P}\right)$ was determined as the overall flume flow rate minus the flow rate travelling through the two orifices at each weir. The projected hydraulic geometry of the entire wetted chute and weir were used in the Chézy equation to calculate ${ }^{11}$

where:

$$
C_{S / P}=\frac{Q_{S / P}}{A_{S / P}} \sqrt{\frac{P_{S / P}}{A_{S / P} S_{0}}},
$$

Equation 13.

$$
\begin{aligned}
& C_{S / P}=\text { Chézy coefficient calculated using } \mathrm{Q}_{\mathrm{S} / \mathrm{P}}\left(\mathrm{ft}^{1 / 2} / \mathrm{s}\right), \\
& Q_{S / P}=\text { sum of } \mathrm{Q}_{\mathrm{ST}} \text { and } \mathrm{Q}_{\mathrm{PL}}(\mathrm{csf}), \\
& A_{S / P}=\text { wetted area over the entire weir }\left(\mathrm{ft}^{2}\right), \\
& P_{S / P}=\text { wetted perimeter over the entire weir }(\mathrm{ft}) .
\end{aligned}
$$

Experimental Methodology

The model fishway was designed with tapered legs attached to the bottom of the structure to provide an $8 \%$ slope. The flume head tank was filled to the desired stage height that corresponded to a flow rate determined from a calibration curve. Flume flow rates were selected based on Froude scaling of the design range of prototype flow rates. Once the flume head tank stage remained steady, the tail water height was adjusted such that the drop over the lowermost weir was similar to the drops over the upstream weirs. To develop a water surface profile and determine the Chézy coefficient, the x-, y-, and z-coordinates along the fishway were recorded. Starting at the furthest downstream weir, measurements were taken in the middle of the fishway over the center of the weir. Two measurements were recorded directly over the weir: the water surface elevation and the height of the weir crest. Moving upstream, these measurements were repeated for each weir. When the fourth weir was reached, additional water surface elevation measurements were taken along the centerline in the middle five fishway pools to create a water surface profile depicting the hydraulic jumps that occurred between weirs. Successive measurements continued until the third weir from the top of the fishway was reached. Intermittent measurements were not taken for the first three or final two weirs to eliminate tailwater and headwater influences on hydraulic modeling.

Measurements were then made on the left and right sides of the fishway at the wetted edge of the weir shoulders. Since there was no water depth at these points, only the heights of the weir crests were measured. These measurements provided the lateral boundary of flow necessary for calculating wetted perimeters and wetted areas. This process was repeated twelve times for nine separate flow rates. For three runs (Run \#5, \#8 and \#11), clay was inserted into the weir orifices to determine how orifice obstruction would affect water surface profiles and Chézy coefficient estimates.

Estimating Wetted Perimeter and Wetted Area

The projection of plunging and streaming portions of flow traveling over each weir within the fishway and experimental measurement locations is illustrated in Figure 7. 


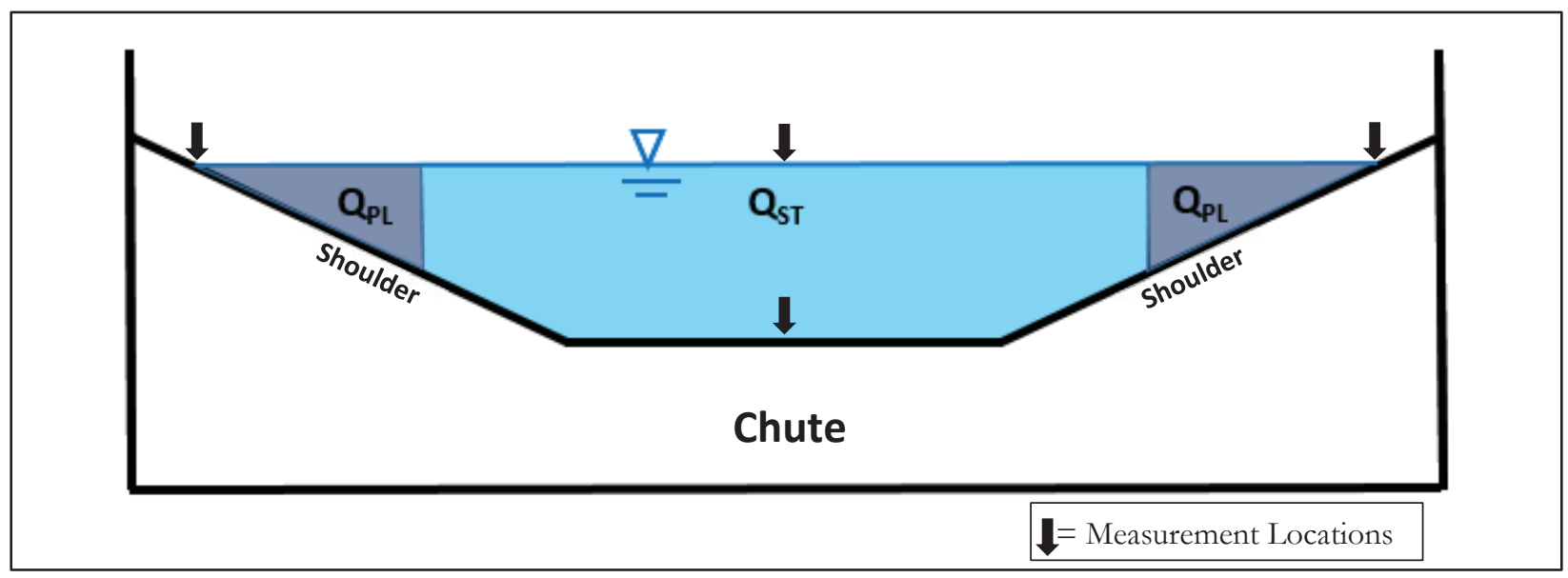

Figure 7. Projection of plunging (Qрг) and streaming (Q Qт) portions of flow over weir crests with experimental measurement locations (Draeger, 2015).

This two-dimensional geometry was used to estimate wetted perimeters and wetted areas of flow. For the streaming flow method, calculations neglected the boundary between Q calculated based on the depth of flow measured directly over the center of the horizontal weir crest. The area was bounded laterally by the geometric location in the projection of $\mathrm{H}_{\mathrm{PT}}$, the depth at the theoretical boundary between $\mathrm{Q}_{\mathrm{PL}}$ and $\mathrm{Q}_{\mathrm{ST}}$. Plunging area was estimated by subtracting $A_{S T}$ from the total projected area, $A_{S / P}$. Chézy coefficient and subsequent velocity estimates were calculated using wetted perimeters and wetted areas determined in this manner.

\section{ANALYSIS RESULTS AND DISCUSSION}

The design range of flow rates for the prototype fishway is 20 to $200 \mathrm{cfs} .{ }^{4}$ Froude scaling of prototype flow rates was carried out to determine a range of flow rates to be used in the model fishway. A total of nine flow rates were examined, with three experimental runs analyzed with the VPC fishway orifices obstructed. Though it was found that the flume slope for run \#9 had been inadvertently set at $7.73 \%$, the data was included as the variation was considered small. For run \#12, a flow rate exceeding the design range was used to determine the fishway performance under higher discharge conditions. The model and corresponding prototype flow rates used in this analysis are shown in Table 1.

\begin{tabular}{|l|c|c|c|}
\hline \multicolumn{1}{|c|}{ Run \# } & Fishway Slope & Q $_{\text {Model }}$ (cfs) & QPrototype (cfs) \\
\hline $\mathbf{1}$ & $8.01 \%$ & 0.068 & 58.8 \\
\hline $\mathbf{2}$ & $8.01 \%$ & 0.085 & 73.9 \\
\hline $\mathbf{3}$ & $8.01 \%$ & 0.103 & 89.8 \\
\hline $\mathbf{4}$ & $8.02 \%$ & 0.122 & 106.5 \\
\hline $\mathbf{5}$ (Plugged Orifices) & $8.02 \%$ & 0.122 & 106.5 \\
\hline $\mathbf{6}$ & $8.02 \%$ & 0.137 & 119.8 \\
\hline $\mathbf{7}$ & $8.02 \%$ & 0.165 & 143.5 \\
\hline $\mathbf{8}$ (Plugged Orifices) & $8.02 \%$ & 0.165 & 143.5 \\
\hline $\mathbf{9}$ & $7.73 \%$ & 0.208 & 181.2 \\
\hline $\mathbf{1 0}$ & $8.01 \%$ & 0.253 & 220.2 \\
\hline $\mathbf{1 1}$ (Plugged Orifices) & $8.02 \%$ & 0.253 & 220.2 \\
\hline $\mathbf{1 2}$ & $8.02 \%$ & 0.325 & 283.1 \\
\hline
\end{tabular}

Table 1: Fishway slopes along with model and prototype flow rates used in each of the 12 experimental runs.

The Chézy coefficient was estimated for each dataset using the entire projected cross-sectional flow area over the weirs, given by the streaming and plunging flow calculation method described in the methodology section. Additionally, the Chézy coefficients were estimated using the streaming flow calculation method, described in the methodology, for runs with sufficient $H_{P T}$ depths (runs \#4 through \#12). Results of these analyses are presented and discussed in the following subsections.

Chésy Estimates: Streaming Flow Calculation Method

For runs \#4 through \#12, prototype flow rates ranged from 106.5 to 283.1 cfs. Corresponding Chézy coefficient estimates calculated by the streaming flow method varied from 39.2 to $22.3 \mathrm{ft} \mathrm{ft}^{1 / 2} / \mathrm{s}$, respectively. Chézy coefficient estimates were plotted for graphical presentation in Figure 8. 


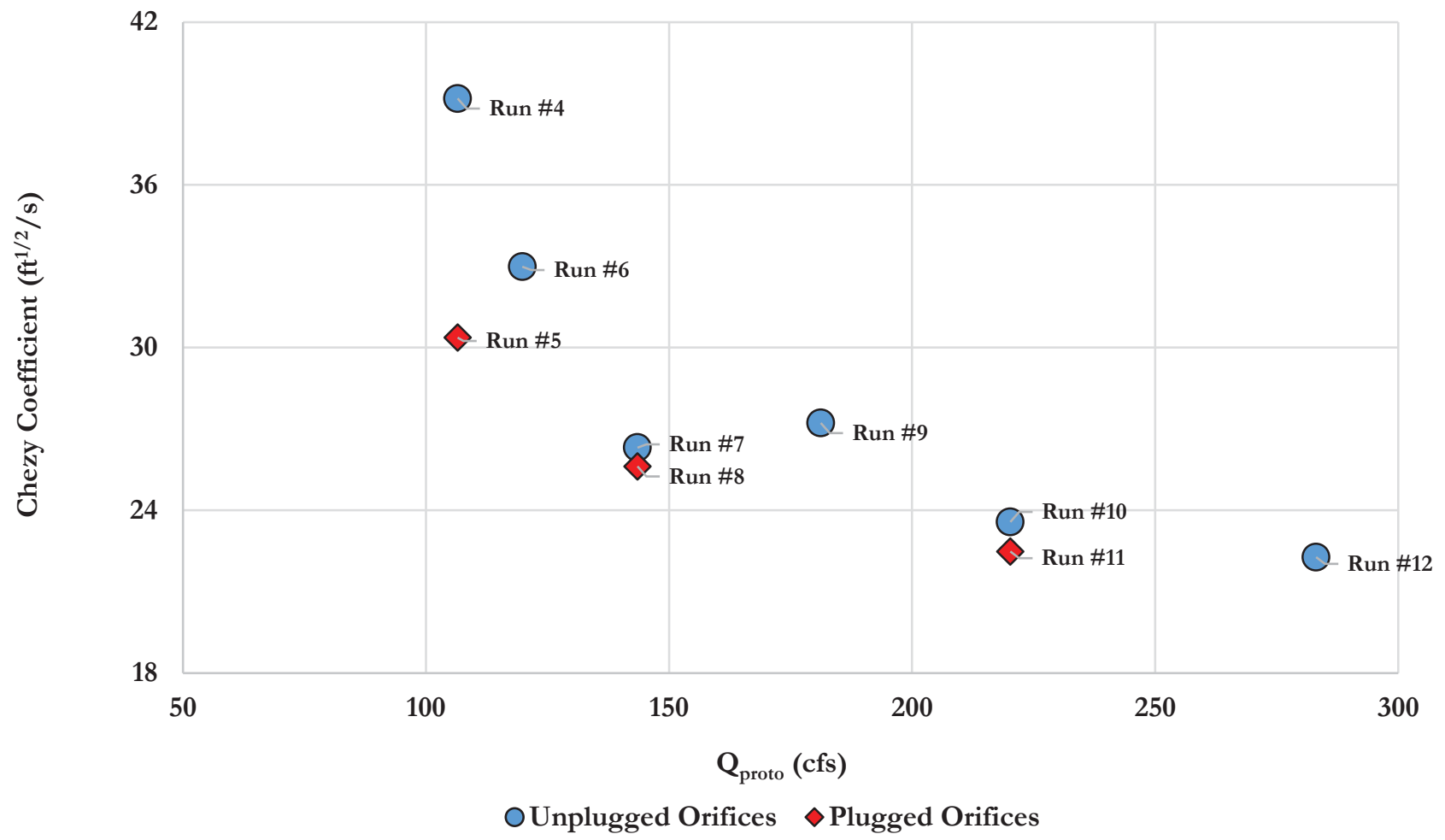

Figure 8. Chézy coefficient estimates using the streaming flow calculation method.

The most apparent observation to be made from the plot shown above is that as flow rates increase, flow resistance also increases and the resulting Chézy coefficient values decrease in magnitude (Figure 8). Also seen is that for equivalent flows, in general, the Chézy approximation is lower when the fishway orifices are plugged. Each of these outcomes suggests that the influence of the weirs increases as the water depth rises. Therefore, the fishway contributes more resistance as discharge increases when both streaming and plunging flow regimes exist.

An unexpected result from this portion of the analysis is the large Chézy coefficient value of $39.2 \mathrm{ft}^{1 / 2} / \mathrm{s}$ determined for Run \#4, with a prototype flow rate of $106.5 \mathrm{cfs}$. A Chézy coefficient value of $30.4 \mathrm{ft}^{1 / 2} / \mathrm{s}$ was estimated at the same flow rate with plugged orifices, resulting in a $29 \%$ difference between the two Chézy coefficients. Conversely, changes of only 2-3\% were observed between plugged and unplugged Chézy coefficient estimates for the $143.5 \mathrm{cfs}$ and $206.3 \mathrm{cfs}$ flow rates.

Despite careful review of measurement data entry and calculations, no conclusive justification was established for the Run \#4 Chézy coefficient estimates to be considered erroneous. The second set of measurements collected at the 106.5 cfs flow rate yielded similar results. It is noteworthy to point out that at this flow, the average water surface depth over the horizontal weir sections was $0.086 \mathrm{ft}$, compared to the theoretically calculated transition depth $\left(H_{P T}\right)$ of $0.082 \mathrm{ft}$. The authors suspect that the narrow margin between the theoretical $H_{P T}$ value and the average measured flow depth over the horizontal weirs contributed to the extreme Chézy coefficient estimate for run \#4 using the streaming flow calculation method. It is also noted that the theoretical $H_{P T}$ value was calculated using Equations 15 and 16, assuming transition flow to occur over horizontal weirs. Furthermore, since run \#4 corresponded to the lowest rate with streaming flow; and thus, lowest water depth, error in depth measurements may have had greater influence on the resulting Chézy coefficient estimates. All other Chézy coefficients estimated using the streaming flow calculation method fell within the range of $22-30 \mathrm{ft}^{1 / 2} / \mathrm{s}$ found in literature for fishway slopes between $4.6 \%$ and $11.1 \%{ }^{11}$

Chézy Estimates: Streaming and Plunging Flow Calculation Method

Chézy coefficients determined by the streaming and plunging flow calculation method ranged from 18.9 to $41.9 \mathrm{ft}^{1 / 2} / \mathrm{s}$. The results are shown for visual presentation. 


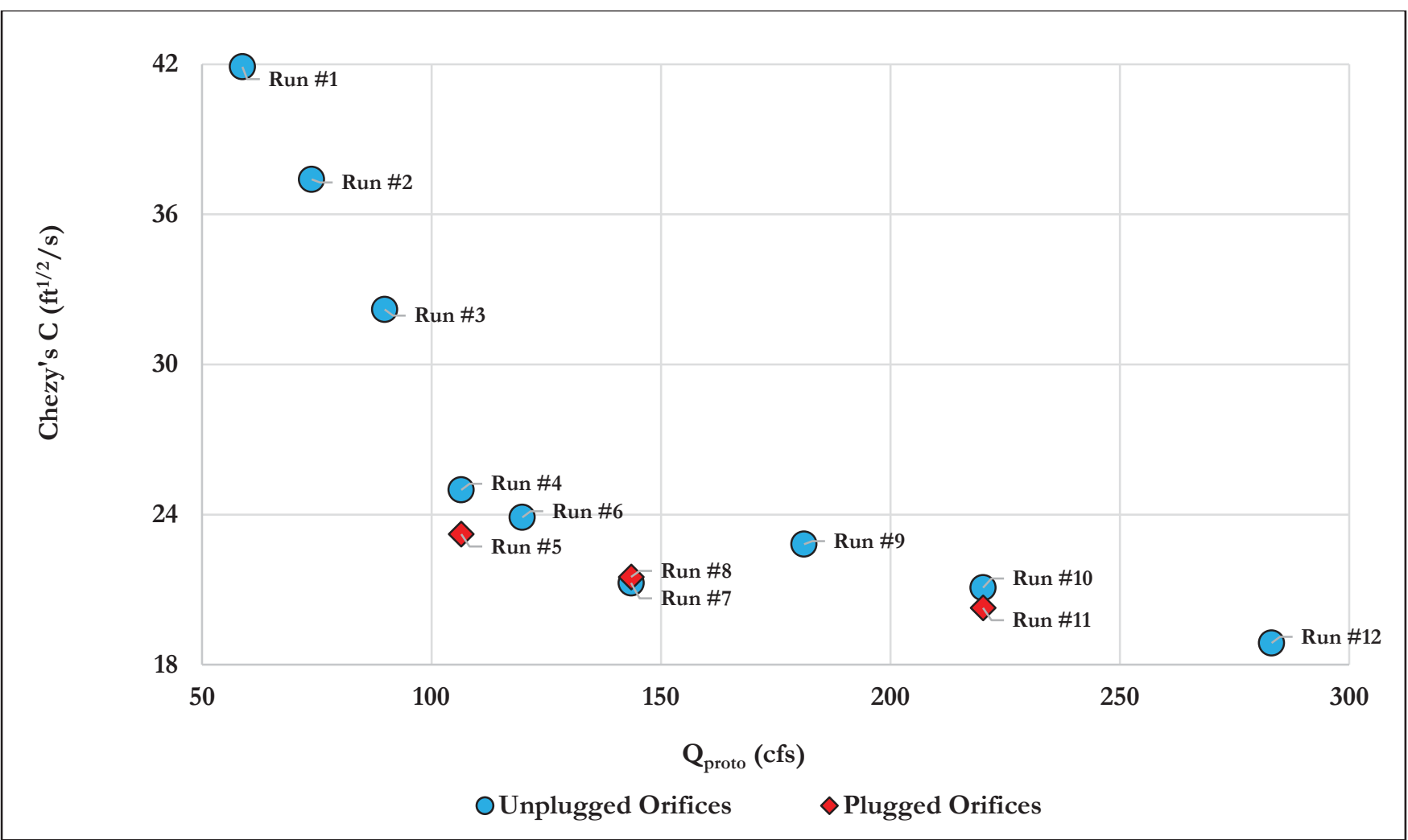

Figure 9. Chézy coefficient estimates using streaming and plunging flow calculation method.

As with the previous calculation method, a general trend is observed in which Chézy estimates decrease with increasing flow rate (Figure 8 and Figure 9). Figure 9 shows the Chézy coefficient decreases much more rapidly in response to increased plunging flows, before streaming flow begins. A fairly linear relationship appears to exist between Chézy estimates and flow rate with an abrupt transition zone as streaming flow begins at approximately $105 \mathrm{cfs}$. The most noticeable difference between the estimates shown in Figure 9 and those found using only the streaming cross-sections is that there is far less variance within corresponding flow rates, largely due to the outlier in the preceding set. Chezy coefficients were found to be systematically lower when estimated using the streaming and plunging flow calculation method versus those computed by the streaming flow method. The streaming and plunging flow calculation method does not require approximations of $Q_{P T}, Q_{P L}$, and $H_{P T}$ to estimate Chézy coefficients. Neglecting these theoretical values in the calculations may have contributed to the lower variance between estimates, and the lower Chézy coefficient estimates in general.

The Chézy estimates for flow rates where plugged versus unplugged orifices were compared only vary by $1-7 \%$. As with streaming flow calculations, the largest difference was observed at the lowest flow rate. However, considering the relatively small change in flow that resulted, $7 \%$ is a reasonable difference relative to $29 \%$, supporting suspicions of the validity of the $106.5 \mathrm{cfs}$ streaming flow calculation.

Water Surface Profiles

Water surface elevations were collected at six intermediate locations along the centerline of the pools between the middle six weirs. With elevations measured directly over the center of each weir, information was provided about the change in elevation for consecutive pools, as well as the location, magnitude, and distribution of hydraulic jumps. Visual representations of unplugged orifice profiles for prototype equivalent flow rates of 106.5, 143.5, 181.2 and $283.1 \mathrm{cfs}$ are shown below. 


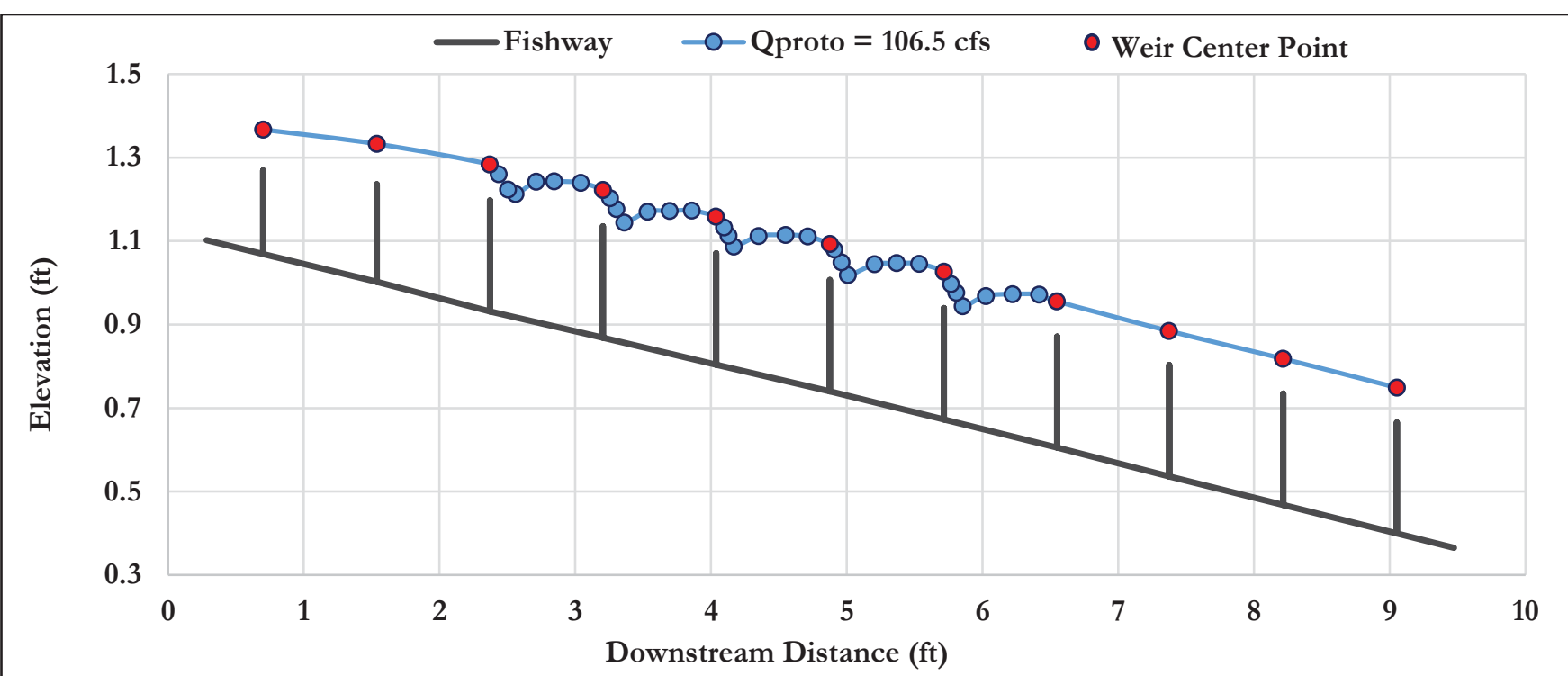

Figure 10. Water surface profile for $106.5 \mathrm{cfs}$ prototype equivalent.

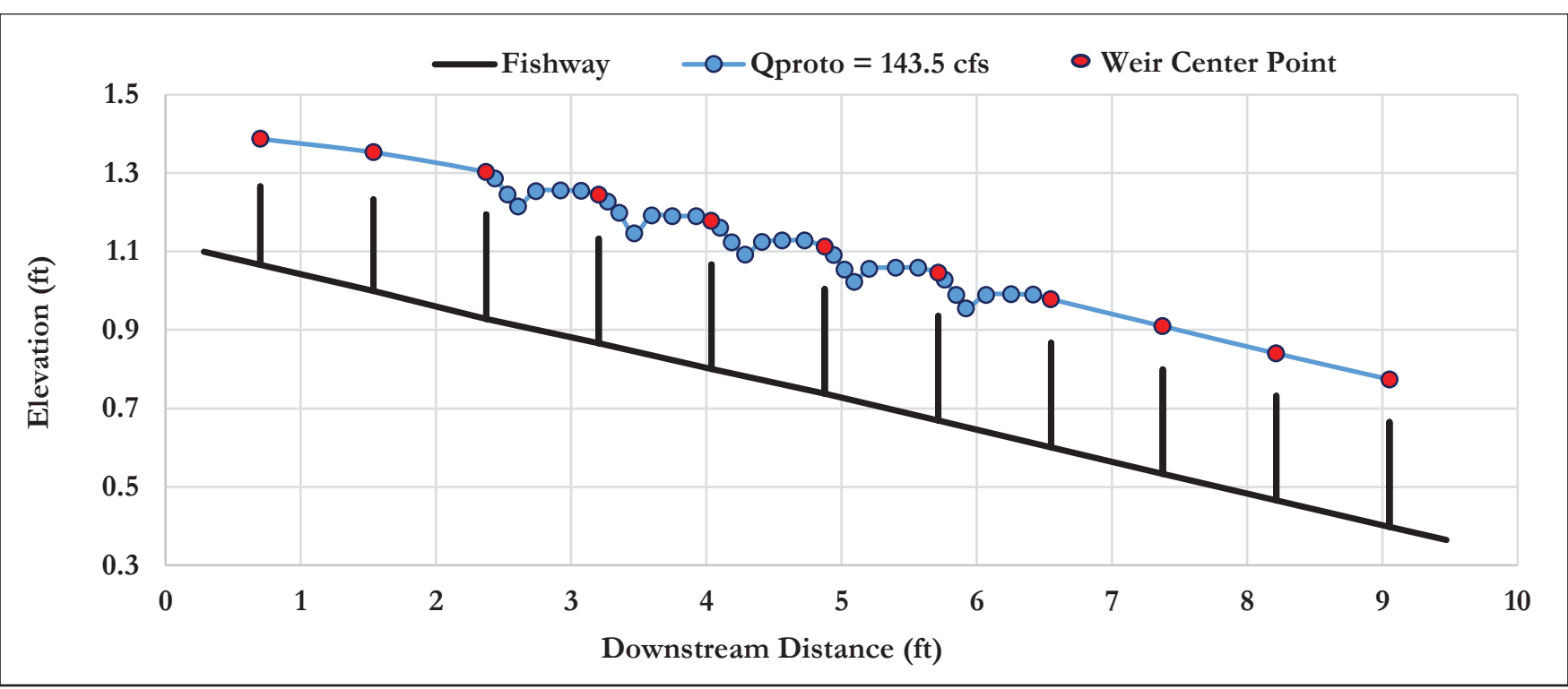

Figure 11. Water surface profile for $143.5 \mathrm{cfs}$ prototype equivalent. 


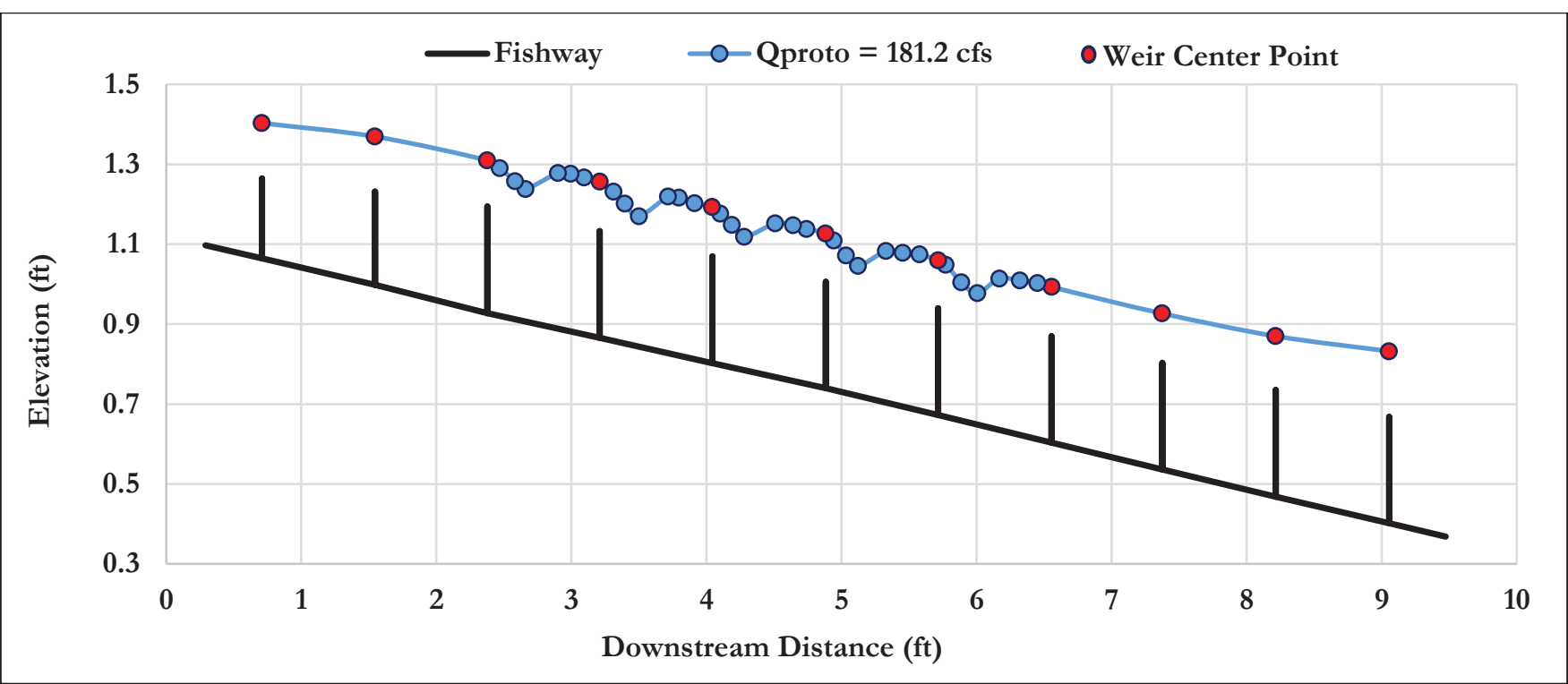

Figure 12. Water surface profile for 181.2 cfs prototype equivalent.

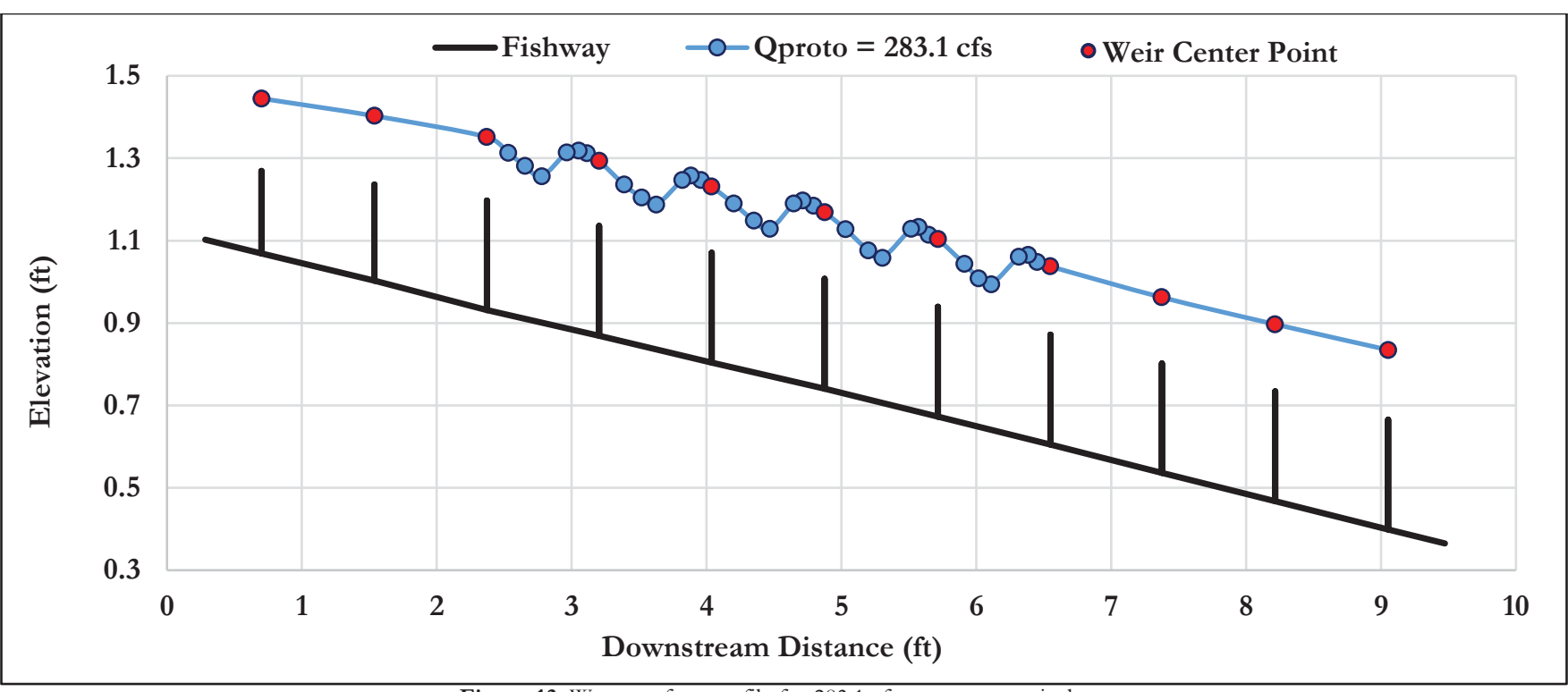

Figure 13. Water surface profile for $283.1 \mathrm{cfs}$ prototype equivalent.

Examination of the water surface profiles shows the effects of momentum with increasing flow. This can be seen by the increasing magnitude of the hydraulic jump heights with increasing flow rates (Figure 10 -Figure 13). The water is also observed to drop over the weirs more abruptly for the lower flow rate runs, shown by the steeper downward slopes in the water surface profiles immediately downstream of the weirs. For the highest flow rate run, shown in Figure 13, the hydraulic jumps are shown to attain heights well above the water surface elevations located immediately above the weir crests.

During experimentation, it was observed that the water surface elevations near the walls of the fishway, where velocities were low, were substantially greater than those near the center of the channel, where velocities were high. Measurements were taken at the wetted edge of shoulder weirs where the water first started to plunge over the weir crests. Plots were generated to illustrate this effect for run \#9 and run \#12. 


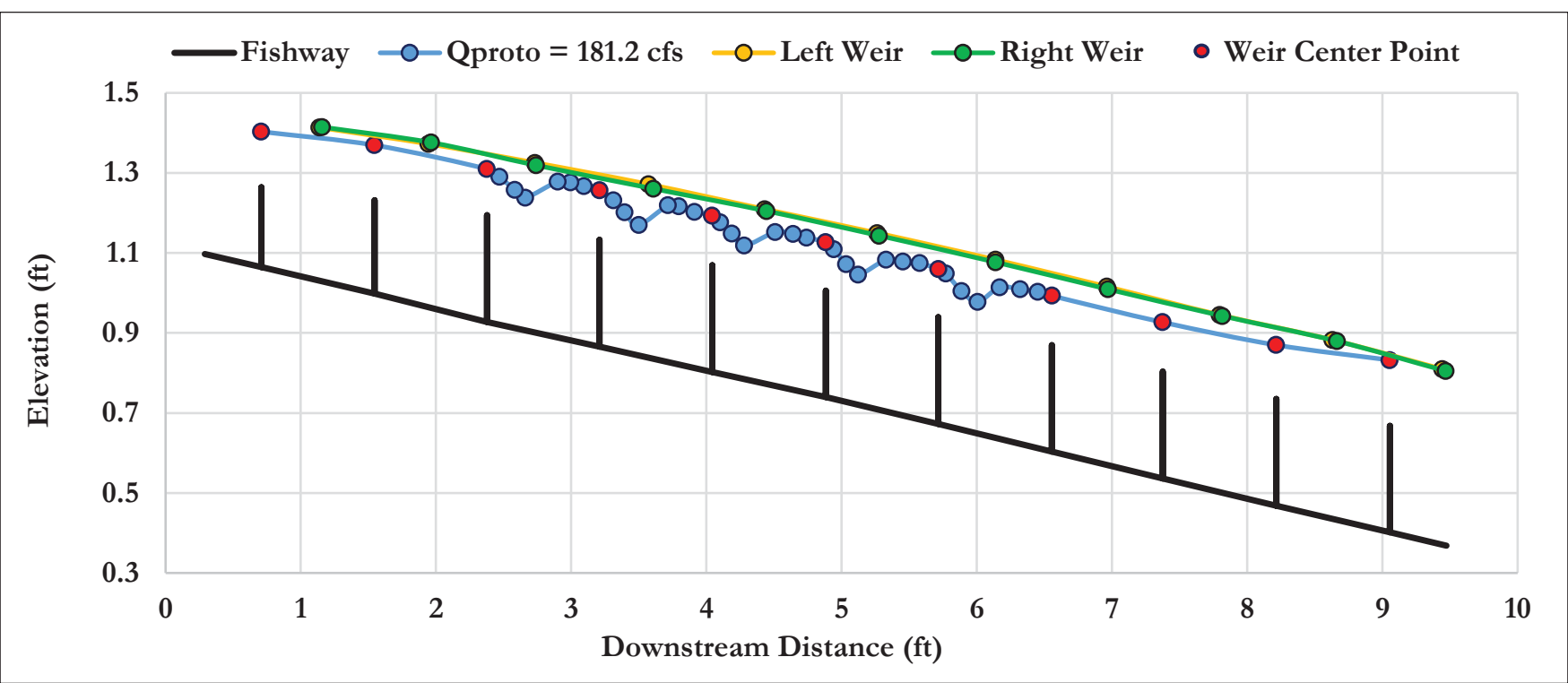

Figure 14. Water surface elevations at left, right, and center weirs for run $\# 9$ ( $\left.Q_{\text {proto }}=181.2 \mathrm{cfs}\right)$.

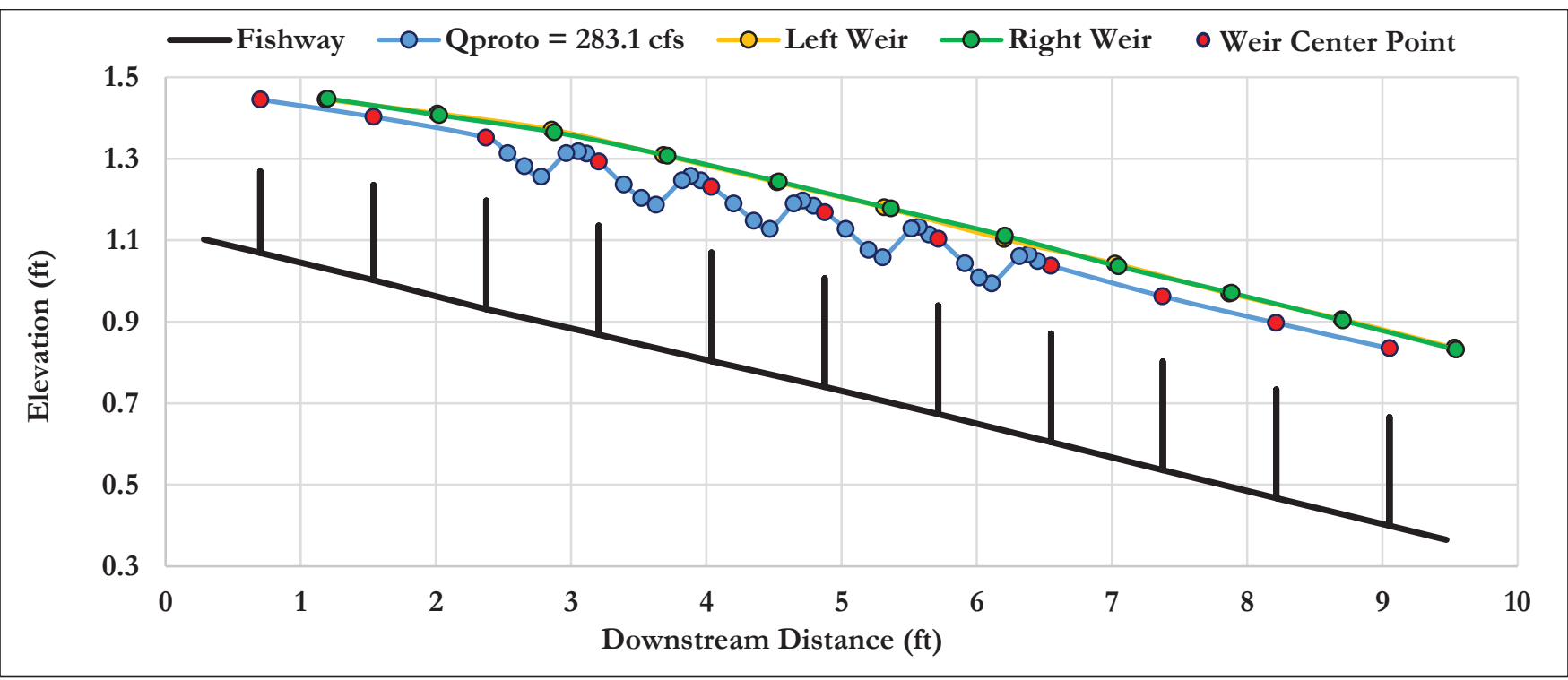

Figure 15. Water surface elevation at left, right, and center weirs for run \#12 (Qproto $=283.1 \mathrm{cfs})$.

Intermediate water surface elevations were not measured between the left and right shoulder weirs. Therefore, the water surface profiles for the shoulder weirs do not depict the plunging flow over weir crests, but merely illustrate the difference in water surface elevations between the center weirs and the shoulder weirs. For run \#12, the highest flow rate run (283.1 cfs), the left and right weir profiles were in contact with the walls of the fishway (Figure 15).

\section{Plugged Orifices}

To test the effect of orifice obstructions within the fish passage, the orifices were plugged with clay for three of the flow rates analyzed $(106.5,143.5$ and $220.2 \mathrm{cfs})$. Though obstructing the orifices had measurable effects when compared to the unplugged profiles, the differences were relatively small and diminished with increased flows. 


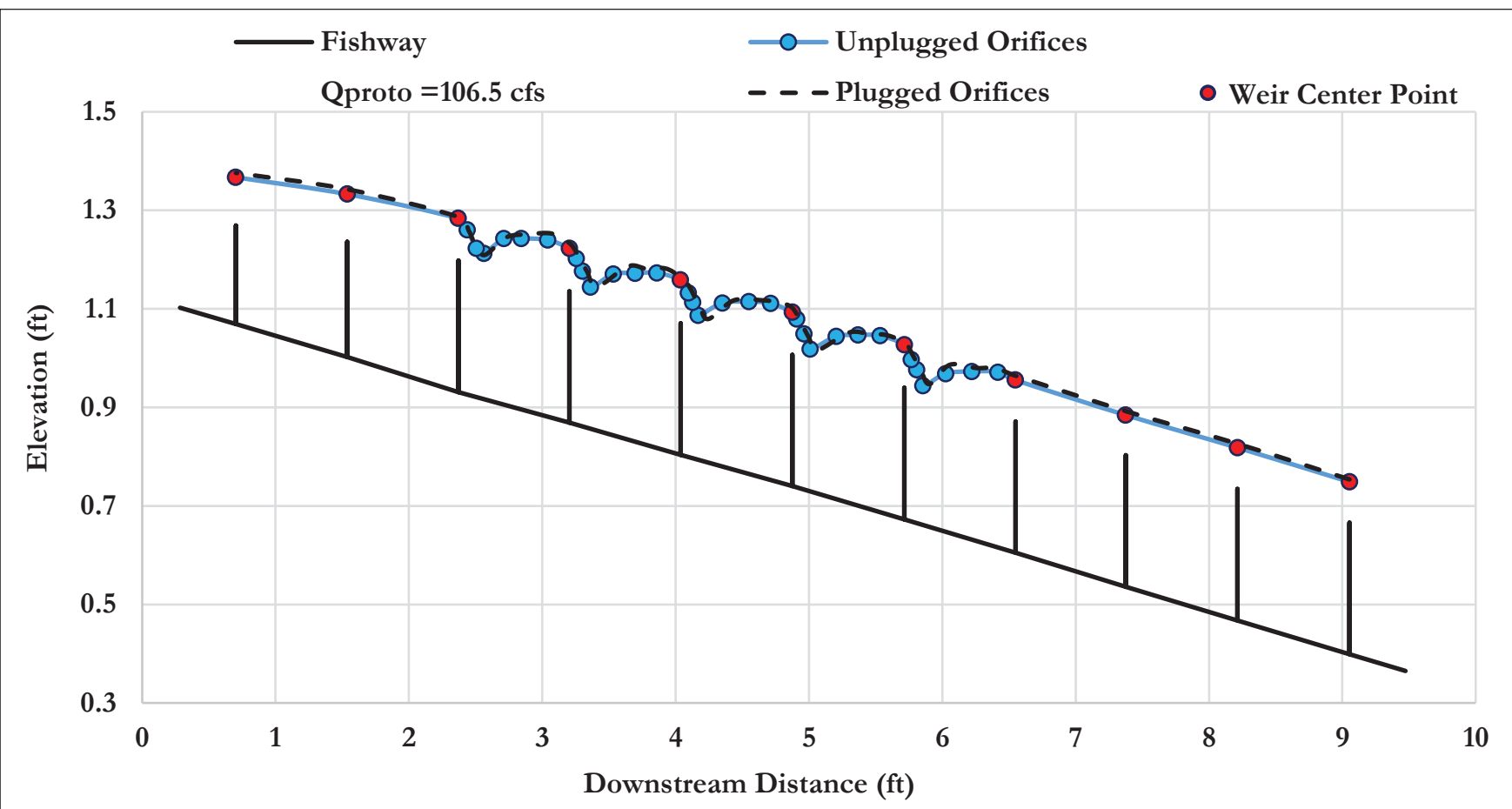

Figure 16. Plugged versus unplugged water surface profiles for 106.5 cfs prototype equivalent (runs \#4 and \#5).

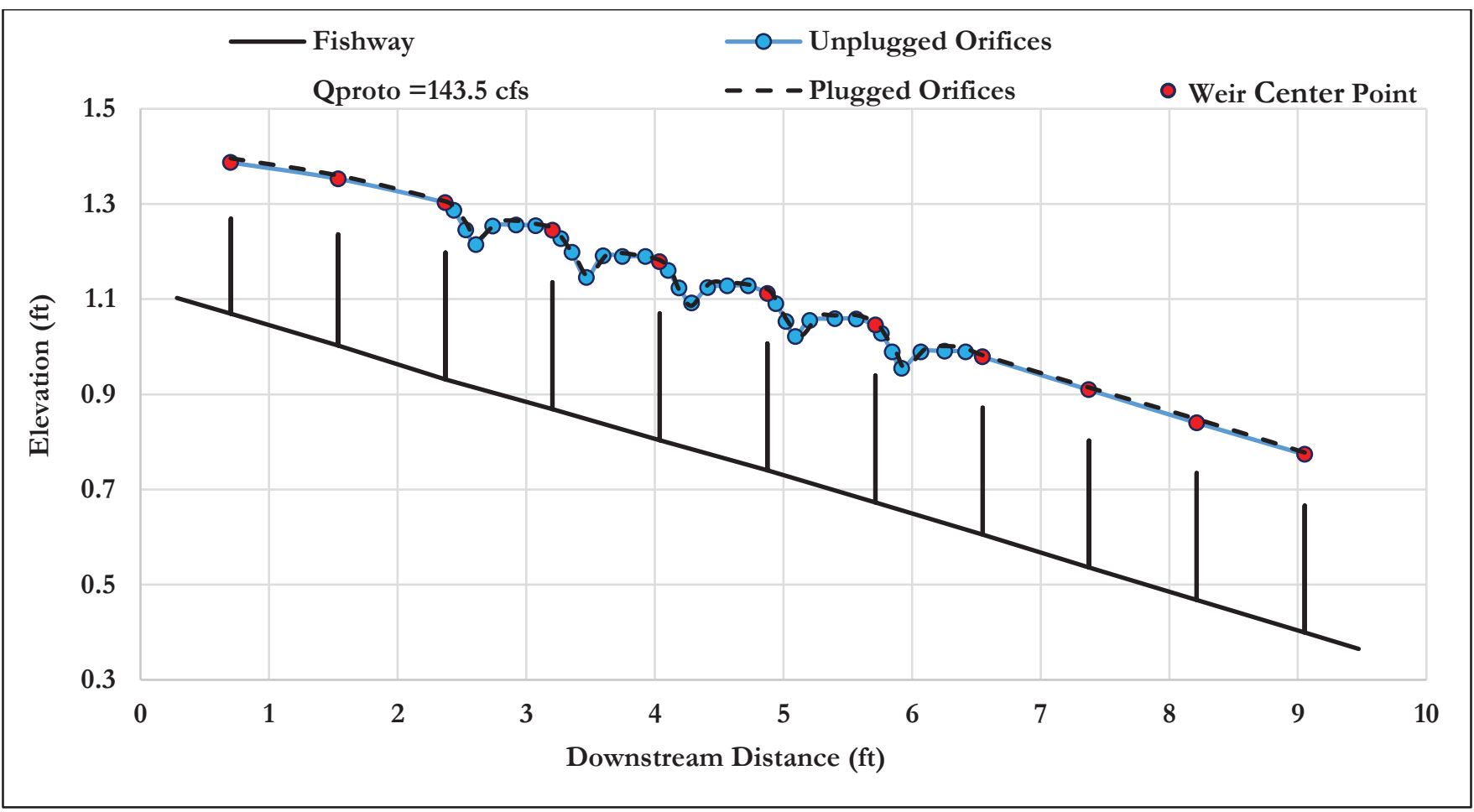

Figure 17. Plugged versus unplugged water surface profiles for 143.5 cfs prototype equivalent (runs \#7 and \#8). 


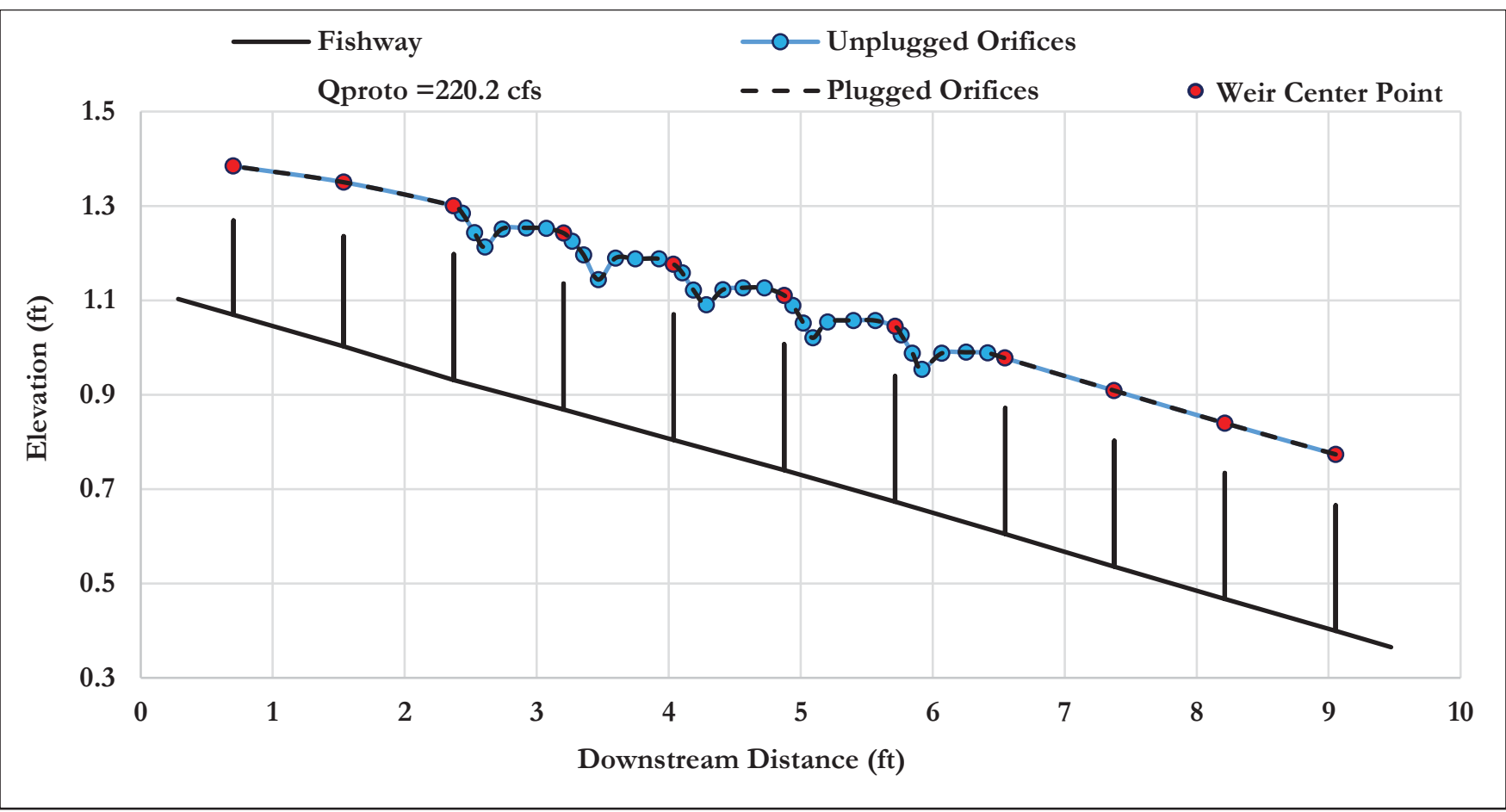

Figure 18. Plugged versus unplugged water surface profiles for 220.2 cfs prototype equivalent (runs \#10 and \#11).

The influence that plugged orifices had on elevating the water surface profile and the hydraulic jumps is indistinguishable at the highest flow rate. This is because orifice flow is held constant, assuming the water surface drop across the shoulder weirs remains the same with varying flows and plugging orifices adds a proportionally smaller amount of flow over the shoulders at larger flow rates.

\section{Flow velocities}

To confirm that flow conditions within the structure were favorable for fish attraction and passage, streaming and plunging prototype fishway average velocities were calculated for each flow rate, by dividing out projected areas.

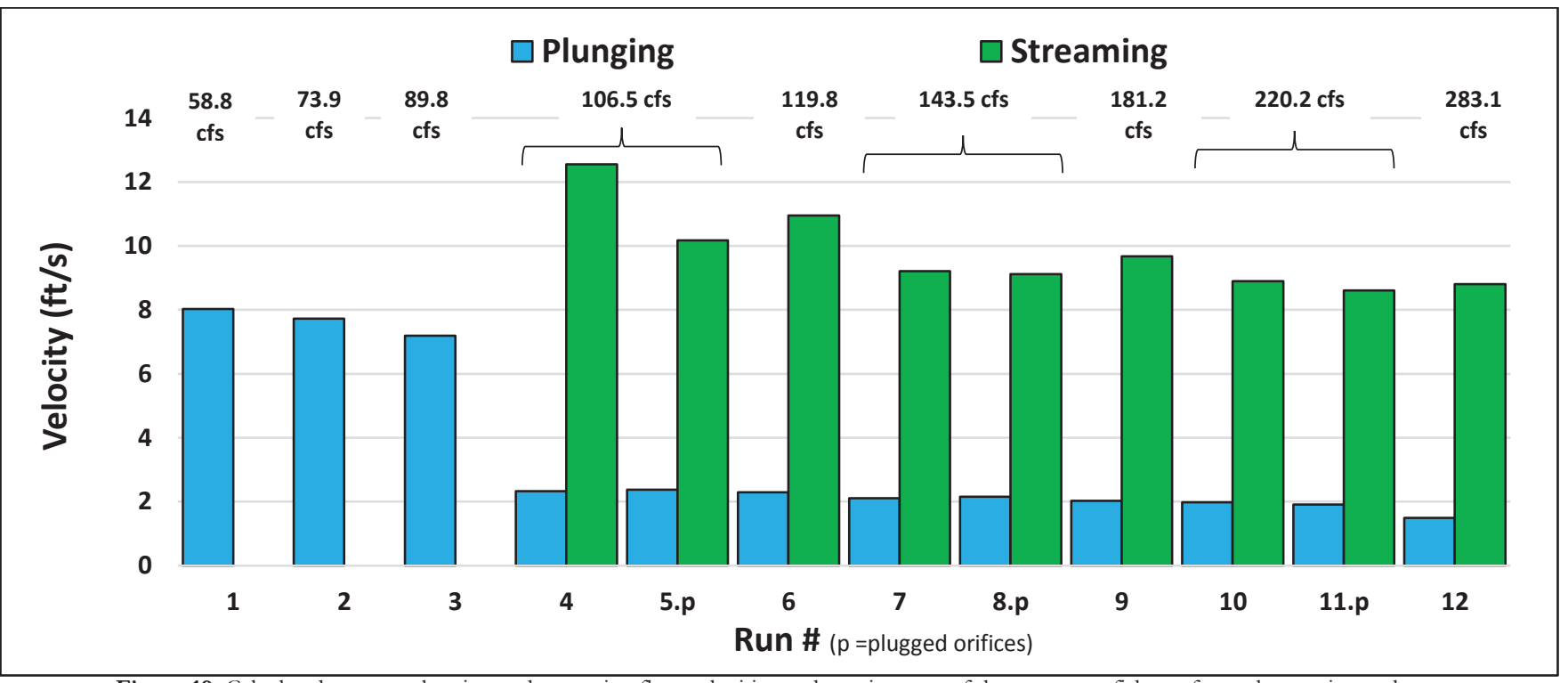

Figure 19. Calculated average plunging and streaming flow velocities at the weir crests of the prototype fishway for each experimental run.

For runs with plunging flow only, velocity was observed to decrease with increasing flows. Due to greater downstream pool depths at increasing flow rates, plunging flow energy was more effectively dissipated by larger pool volumes. A similar trend was 
observed for streaming flow velocities. As flows increased, the location of the hydraulic jump, where flow slows from supercritical to subcritical, moved further into the downstream pools, which reduced the acceleration distance to the subsequent weir. The magnitude of the hydraulic jump height was also observed to increase, indicating greater energy dissipation due to turbulence in the pools at higher flow rates (Figure 10-Figure 13). Though the streaming flow velocities varied with flow rate, the plunging flow velocities remained fairly constant with the exception of run \#12, where the plunging regime geometry may have been influenced by the sidewalls of the fishway. The plunging velocities were calculated to be approximately two ft/s for all runs where both streaming and plunging flows were observed. It is noted that these velocities are for the flows over the weir crests; velocities within the pools of the fishway appeared slower by visual inspection but were not quantified.

\section{Sensitivity Analyses}

A sensitivity analysis was conducted to determine the effects that changes in the recorded flume flow rates would have on the estimated Chezy coefficients. Imprecise readings of the stage in the flume head tank, the error introduced by the use of the discharge calibration curve, and small amounts of leakage bypassing the fishway may have contributed to the use of inaccurate discharge values in the estimation of Chezy coefficients. For example, an error of one-eighth inch in the stage reading would result in a $14 \%$ error in discharge for run \#1 (58.8 cfs) and a 7\% error for run \#12 (283.1 cfs). Considering this possibility, the recorded flume flow rates were varied by $\pm 5 \%, 10 \%$, and $15 \%$. The results of the sensitivity analyses are graphically presented below for both the streaming flow and the combined streaming and plunging flow calculation methods.

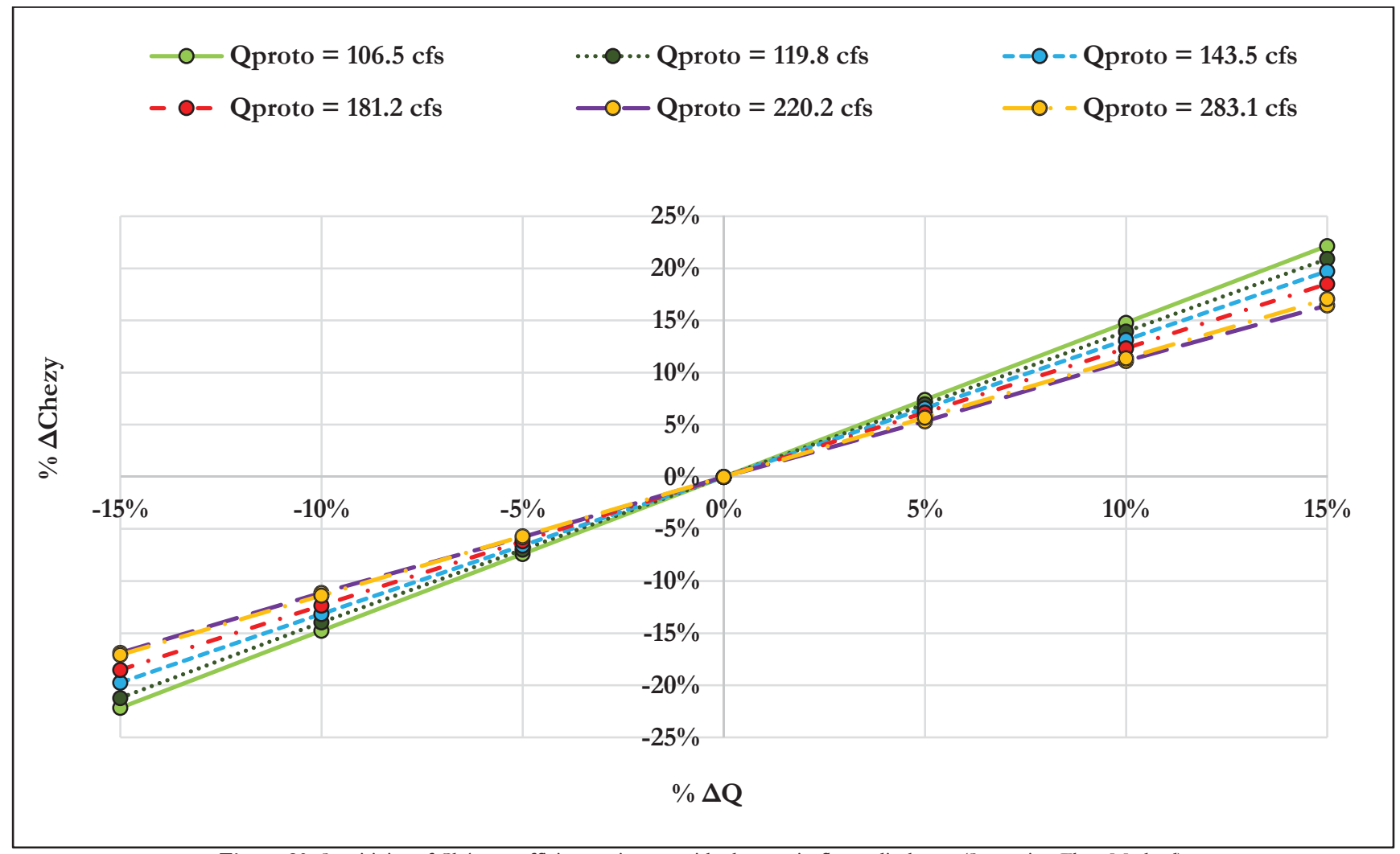

Figure 20. Sensitivity of Chézy coefficient estimates with changes in flume discharge (Streaming Flow Method). 


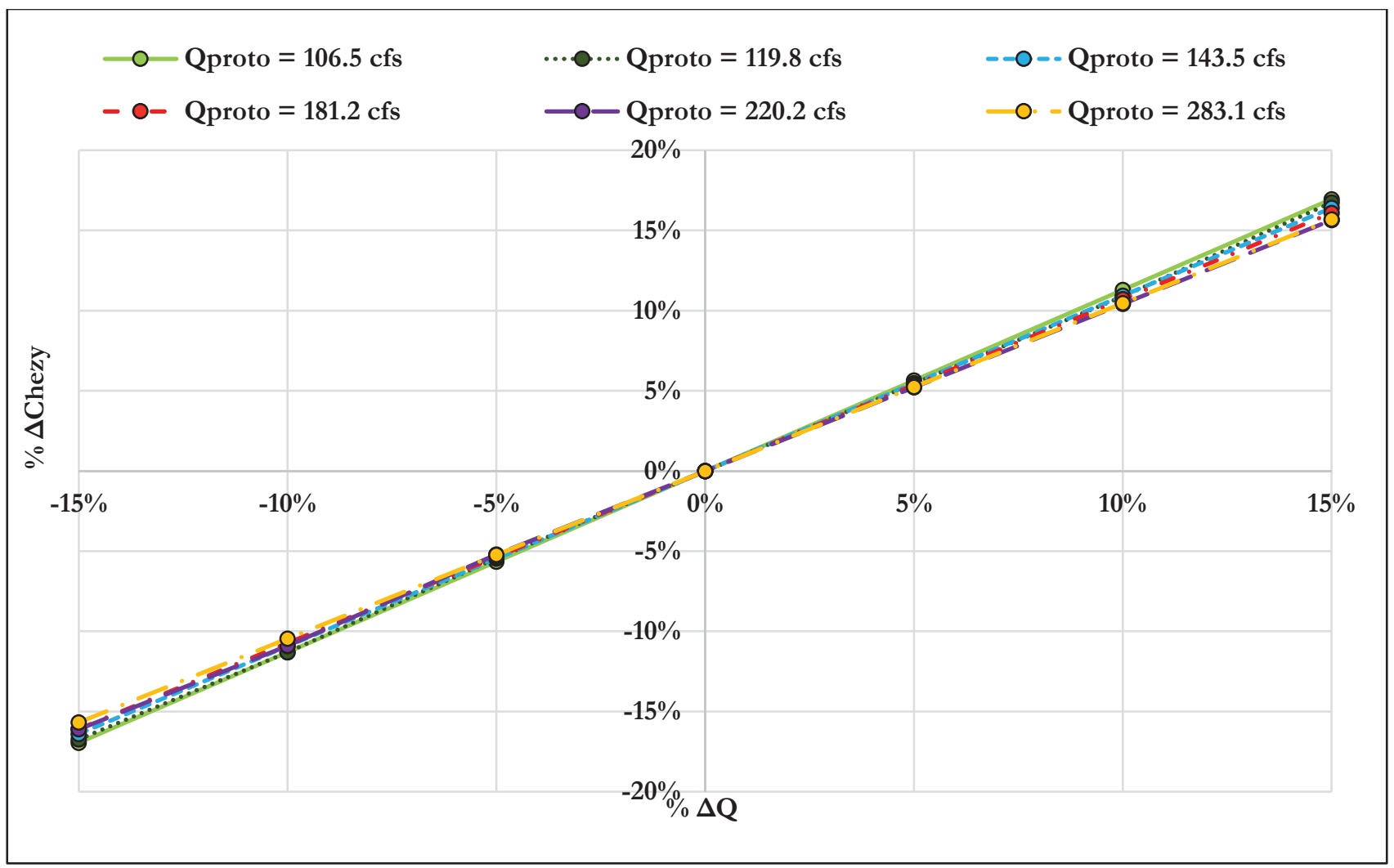

Figure 21. Sensitivity of Chézy coefficient estimates with changes in flume discharge (Streaming and Plunging Flow Method).

From Figure 20 and Figure 21, positive linear relationships are observed between increases in flume discharge rates and Chézy coefficient estimates. This relationship is similar for all unplugged flow rates with streaming and plunging regimes using both calculation methods. The effect is slightly more pronounced for the streaming calculation method as shown by the steeper slopes in Figure 20. The results indicate that if the actual flume discharge was less than the discharge recorded and subsequently used for estimating the Chézy coefficients, then the Chézy values would be less than those reported in this analysis. The opposite would be true for higher discharge rates. For a systematic error in stage reading, the impact on Chézy values would be more pronounced at lower flow rates. For example, a one-eighth inch stage reading discrepancy for run \#1 would result in a 14\% difference in flow rate translating to a $20 \%$ difference in the Chézy coefficient, while the same discrepancy for Run \#12 would result in a $7 \%$ difference in flow rate, impacting the Chézy estimate by approximately $8 \%$.

As previously mentioned, the streaming flow calculation method required values calculated with the theoretical relationships presented by Equations 7 thru 10. The water depth at which the flow regime transitioned from plunging to streaming flow $\left(H_{P T}\right)$ was determined using Equations 7 and 8. These equations assumed the transition depth to occur over the horizontal portion of the weir crests; however, the transition between streaming and plunging flows occurred over the sloping shoulder portion of the weirs. The authors neglected to incorporate a correction factor to account for this difference. Therefore, actual transition flow depths may have been less than the theoretically calculated value of $0.082 \mathrm{ft}$ (model fishway), which was subsequently used to determine the streaming flow cross-sectional areas used in the Chézy equation. A sensitivity analysis was conducted to determine the effects that decreases in the theoretically determined $H_{P T}$ value would have on the Chézy coefficients estimated by the streaming flow calculation method. The $H_{P T}$ value was reduced by up to $30 \%$, in $5 \%$ increments. The results are graphically presented below. 


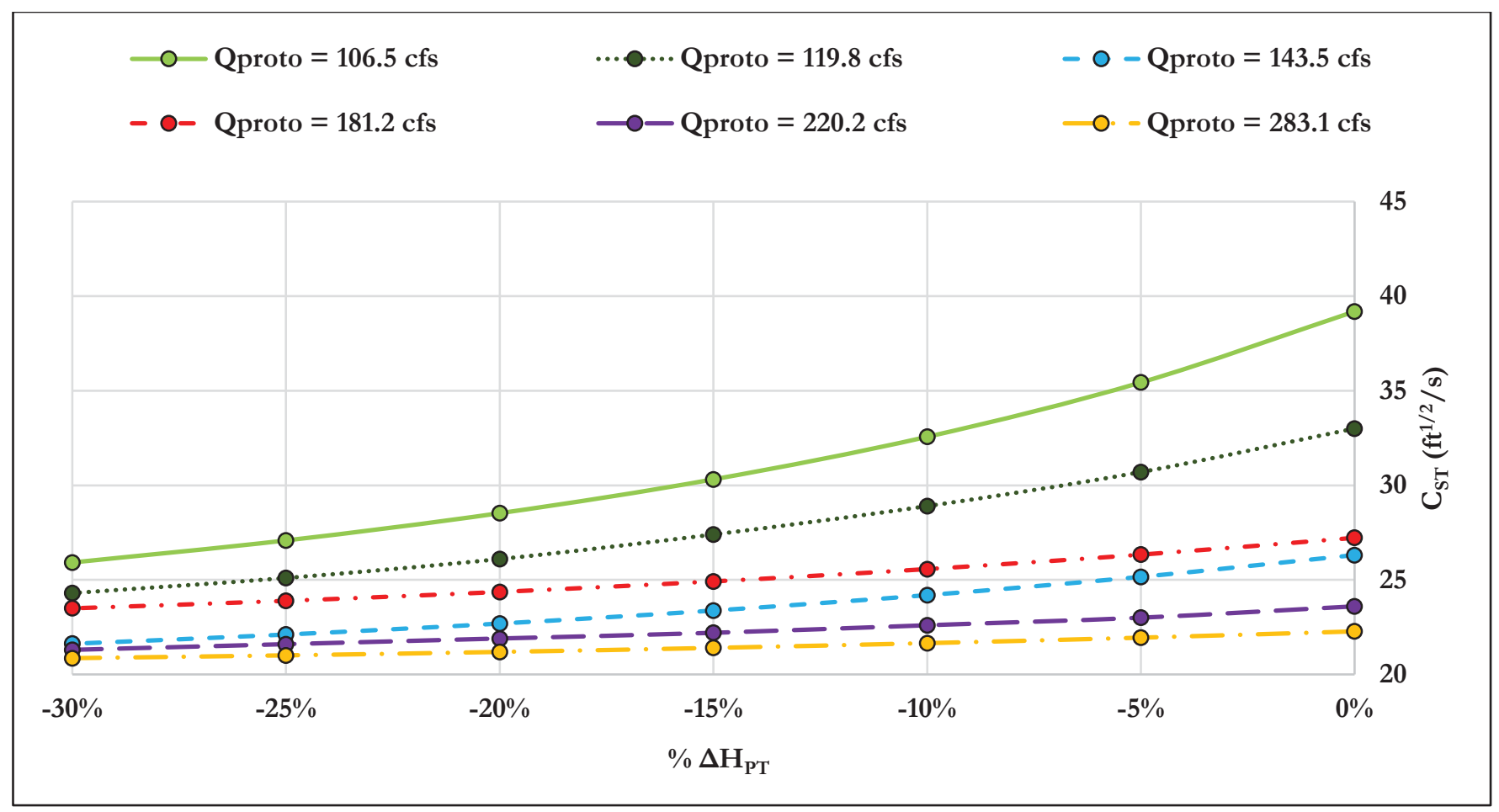

Figure 22. Sensitivity of Chézy coefficient estimates with changes in $\mathrm{H}_{\mathrm{PT}}$ (Streaming Method).

From Figure 22, decreases in the theoretically calculated transitional flow depth $\left(H_{P T}\right)$ are shown to result in decreases in the Chézy coefficient estimates calculated by the streaming flow method. The effect is observed to be more dramatic at lower flow rates where equivalent changes have a proportionally greater impact on streaming flow. Run \#4 and run \#5 had the lowest flow rates, Figure 22 shows that the Chézy estimates for these runs are substantially smaller with reductions in $H_{P T}$ as little as $10 \%$. Conversely, run \#12 was the run with the greatest flow rate $\left(Q_{\text {model }}=0.325 c f s\right)$, and a reduction in $H_{P T}$ as great as $30 \%$ only resulted in a $6.4 \%$ decrease in the Chézy coefficient estimate. The results indicate that if error was introduced into the Chézy coefficient estimations using the streaming flow calculation method, then the estimates reported in this analysis would be overestimates of the true values. It is also noted that a comparison between Figure $\mathbf{8}$ and Figure $\mathbf{9}$ reveals that the streaming flow calculation method did indeed result in greater Chézy coefficient estimates relative to those computed using the streaming and plunging flow method.

\begin{tabular}{|c|c|c|c|}
\hline Run \# & $Q_{\text {Prototype }}(\mathrm{cfs})$ & $\mathrm{C}_{\text {Streaming }}\left(\mathrm{ft}^{1 / 2} / \mathrm{s}\right)$ & $\mathrm{C}_{\text {Streaming and Plunging }}\left(\mathrm{ft}^{1 / 2} / \mathrm{s}\right)$ \\
\hline 1 & 58.8 & No streaming flow & 41.9 \\
\hline 2 & 73.9 & No streaming flow & 37.4 \\
\hline 3 & 89.8 & No streaming flow & 32.2 \\
\hline 4 & 106.5 & 39.2 & 25.0 \\
\hline 5 (Plugged Orifices) & 106.5 & 30.4 & 23.2 \\
\hline 6 & 119.8 & 33.0 & 23.9 \\
\hline 7 & 143.5 & 26.3 & 21.3 \\
\hline 8 (Plugged Orifices) & 143.5 & 25.6 & 21.5 \\
\hline 9 & 181.2 & 27.2 & 22.8 \\
\hline 10 & 220.2 & 23.6 & 21.1 \\
\hline 11 (Plugged Orifices) & 220.2 & 22.5 & 20.3 \\
\hline 12 & 283.1 & 22.3 & 18.9 \\
\hline
\end{tabular}

Table 2. Comparison of Chézy coefficient estimates for streaming flow method and streaming and plunging flow method.

Therefore, the authors recommend that a correction factor be incorporated into future analyses since horizontal weir equations were used to approximate $H_{P T}$, when in fact transition from plunging to streaming flows occurred over the sloped shoulder portion of the weirs. 


\section{CONCLUSIONS}

The results of this analysis include Chézy coefficient estimates for the model vortex pool-and-chute fishway, designed by Michael Love and Associates. The coefficients were calculated by two different methods, the streaming flow method and the streaming and plunging flow method, each based on the portion of flow used as the discharge in the Chézy equation. Chézy coefficient estimates ranging between 22.3 and $30.4 \mathrm{ft}^{1 / 2} / \mathrm{s}$, with one outlier value of $39.2 \mathrm{ft}^{1 / 2} / \mathrm{s}$, were determined by the streaming flow calculation method. For the same flows, Chézy coefficient estimates ranging between 18.9 and $25.0 \mathrm{ft}^{1 / 2} / \mathrm{s}$ were calculated by the streaming and plunging flow calculation method and values of 32.2 to 41.9 were calculated for flows that were exclusively plunging. The streaming and plunging flow calculation method resulted in lower Chézy coefficient estimates and less variance between estimates compared to those computed with the streaming flow calculation method. In both cases, results indicate that the fishway provides greater resistance as flows increase throughout the range tested. However, the composite Chézy coefficients based on the two flow regimes not only provide better and more stable results but also afford the ability to estimate the velocity in each regime. The plunging zones along the boundaries of flow over the weirs were found to maintain lower velocities, providing a thin nappe for fish to swim or leap over with little difficulty.

Orifices within the fishway weirs were plugged for 3 of the 12 experimental runs examined in this analysis. The plugged orifice runs were observed to result in mildly elevated water surface profiles relative to unplugged runs at the same flow rates.

Furthermore, slightly lower Chézy coefficient estimates were determined when the orifices were plugged, which may offer a slight advantage to fishway performance at higher flow rates. The ability of the orifices to provide passage at lower flows and sediment conveyance at higher flows should be further examined to ensure that such functionality outweighs the reduction in flow resistance.

Based on velocities over the weir crests, derived from Chézy coefficient estimates, preliminary VPC model fishway results indicate that implementation of a prototype fishway would alter creek flow velocity effectively and sufficiently. Streaming flows through the center of the fishway appear to be adequate for fish attraction, while plunging flow along the edges provides for fish passage. Though pool velocities visually appeared to be lower, this observation should be quantitatively confirmed. Turbulence in the plunging regime corridor is also an important consideration that impacts fish passage effectiveness. The energy dissipation factor (EDF) is a metric used to assess turbulence and should be determined for the fishway pools. Further research is recommended to determine pool velocities and turbulence within the model fishway to ensure that they do not conflict with these findings.

\section{REFERENCES}

1. California Department of Fish and Wildlife (2010) California Salmonid Stream Habitat Restoration Manual, $4^{\text {th }}$ ed., Vol. Two, Part VII, 117, http:/ / www.dfg.ca.gov/fish/resources/ habitatmanual.asp (accessed May 2015)

2. Caltrans (2009) Fish Passage Design for Road Crossings, Chapter 9: Fishways, http:/ / www.dot.ca.gov/ hq/ oppd/fishPassage/Chapter\%209\%20Fishways.pdf (accessed April 2015)

3. Bates, K. (1991) Pool-and-Chute Fishways, American Fisheries Society Symposium, Washington: American Fisheries Society, 268-277

4. Love, M. (2015, April) Email Correspondence with Eileen Cashman, Arcata, CA, U.S.

5. Love, M. (2015) Home: Michael Love \& Associates, http:// h2odesigns.com/(accessed April 2015)

6. Powers, P. (n.d.). Pool and Chute Fishways: Discussion and Design Process.

7. Allen, S., Love, M., and Llanos, A. (2004) Peacock Creek Pool and Weir Fishway, bttp:// www.stream.fs.fed.us/fishxing/case/Peacock/Peacock.Poster.pdf (accessed April 2015)

8. National Marine Fisheries Service (2011) NOAA. Anadromous Salmonid Passage Facility Design, bttp:/ / wmw.westcoast.fisheries.noaa.gov (accessed April 2015)

9. White, F. M. (2011) Fluid Mechanics, 7th ed., 721, McGraw Hill, New York

10. Houghtalen, R. J., Akan, A. O., and Hwang, H. (2010) Fundamentals of Hydraulic Engineering Systems, 4th ed., 186-189 Pearson Higher Education, Boston

11. Love, M. (2015) Vortex Pool and Chute Fishway Calculations. Arcata, CA.

12. Ead, S.A., C. Katopodis, G.J. Sikora, and N. Rajaratnam (2004) Flow Regimes and Structure in Pool and Weir Fishways, Journal of Environmental Engineering and Science, Vol. 3(5), 379-390

http://wmw.researchgate.net/publication/233617887_Flow_regimes_and_structure_in_pool_and_weir_fishways (accessed April 2015)

13. Kindsvater, C.E., and Carter R.W.C. (1957) Discharge Characteristics of Rectangular Thin Plate Weirs, Proceedings of the American Society of Civil Engineers, Journal of the Hydraulics Division, Vol. 83, No. HY6, December 1957, pp. 1-36

14. Villemonte, J. (1947) Submerged -Weir Discharge Studies, Engineering News Record, Vol 866, 54-58, http:// wmw.stream.fs.fed.us/fishxing/fplibrary/Villemonte_1947_Submerged_weir_discharge_studies.pdf (accessed April 2015)

15. Daughtry, R. L., and Franzini, J.B. (1965) Fluid Mechanics, 6th ed. 338-349, McGraw-Hill, New York

16. Engineering Toolbox (2015) Weirs-Flow Rate Measure, http:// www.engineeringtoolbox.com/weirs-flow-rate-d_592.html (accessed April 2015)

17. LMNO Engineering Research and Software Ltd. (1999), Focus on Open Channel Flow, Newsletter Vol 1, http:/ / www.Imnoeng.com/Newsletters/newsletters.htm\#v. 1(17) (accessed April 2015) 


\section{ABOUT THE STUDENT AUTHORS}

Brian Draeger, Mat Nyberg, and Brian Weekly completed this research while pursuing B.S. degrees in Environmental Resources Engineering at Humboldt State University in Arcata, California. The authors share a common interest in the fields of hydrology and hydraulics. The analysis presented in this paper was conducted as a semester project for a River Hydraulics course instructed by Dr. Eileen Cashman. The students' interest and effort toward this project has continued beyond their course work under the direction of Dr. Cashman and Dr. Margaret Lang.

\section{PRESS SUMMARY}

Fish passages play an important role in the preservation of migratory fish species in waterways that are impacted by man-made structures. Fish passages (or fishways) cause resistance to flow and create specific hydraulic conditions sufficient for fish migration. This paper offers methods and results for the effectiveness of a vortex pool-and-chute fish passage design on the basis of Chézy resistance coefficients. 